\title{
Ancient Agropastoral System of the Bolivian Altiplano: a Robust Ecosystem Endangered from Changes in Land-use
}

\author{
Sarah J. d'Apollonia ${ }^{1}$, Henrik Meilby ${ }^{2}$, \& Marten Sørensen ${ }^{1}$ \\ ${ }^{1}$ Department of Plant and Environmental Sciences, Faculty of Science, University of Copenhagen. \\ Thorvaldsensvej 40, 1871 Frederiksberg C, Denmark \\ ${ }^{2}$ Department of Food and Resource Economics, Faculty of Science, University of Copenhagen. Rolighedsvej 25, \\ 1958 Frederiksberg C, Denmark \\ Correspondence: Marten Sørensen, Department of Plant and Environmental Sciences, Faculty of Science, \\ University of Copenhagen. Thorvaldsensvej 40, 1871 Frederiksberg C, Denmark. E-mail: ms@ plen.ku.dk
}

Received: June 30, 2018 Accepted: July 20, 2018 Online Published: August 25, 2018

doi:10.5539/sar.v7n4p70 URL: https://doi.org/10.5539/sar.v7n4p70

\begin{abstract}
The current study examines the challenges and constraints faced by rural, small-herd, llama (Lama glama) agropastoralists of the Bolivian Altiplano. Three different study sites with various degrees of agropastoralism were examined in order to describe the relationship between quinoa (Chenopodium quinoa) and llama production and the implications of land use competition between these two livelihoods. In order to document the impact of land use change, the study also examined the native forage species available to free grazing llamas and their relative importance. Llama pastoralists were interviewed and completed a survey on the perceived importance of native forage plants in grazing llama diets as well as the perceived constraints to llama husbandry. The relative frequency of citation (RFC) index was employed as a measure of relative importance of different native forage plant species. This data was supplemented with further primary data collected from the field using mixed methods involving participatory rural appraisal techniques (PRA), interviews and focus groups. Secondary data was collected from an in-depth literature review, government offices and other relevant institutions. The study presents a detailed list of all cited native forage species and their perceived importance as a forage crop and any ethnoveterinary uses. The results reveal that challenges and constraints can often be site-specific, and a lack of forage throughout the dry season (May to November) was a general constraint among study sites. Quinoa production was found to be in direct competition with llama husbandry, with many sites demonstrating s shift away from llama pastoralism.
\end{abstract}

Keywords: llama husbandry, land-use conflict, sustainable livestock, Bolivia

\section{Introduction}

The United Nations Human Development Index ranks Bolivia $118^{\text {th }}$ out of 188 countries, with $45 \%$ of the population living below the poverty line (UNHDI, 2016). Llama husbandry is recognized as an important element of the Altiplano ecosystem (Barreta et al., 2013; Treydte, Salvatierra, Sauerborn, \& Lamers, 2011; Postigo, Young, \& Crews, 2008; Fairfield, 2004) as it ensures soil fertility and seed dispersal while providing a livelihood and a source of many goods and services for rural communities. Small ruminant (llama and sheep) husbandry is the principal economic activity for more than 54000 rural poor families in Bolivia, while 3000 families pursue llama husbandry as their primary source of income (Barreta et al., 2013; Vera, 2006). Llama husbandry in the Bolivian Altiplano involves traditional agro-pastoral herding in natural pastures. Agropastoralists are defined as people who derive less than $50 \%$ of their income from animals and animal products, and the remainder of their income is predominately derived from the cultivation of crops (Jenet et al., 2016). In the Bolivian Altiplano, community pastures are managed collectively by local peoples (Jenet et al., 2016). Traditionally, communities of the Altiplano would self-govern access and use of community pastures depending on population density, the environment and available resources. Up to $90 \%$ of pasture land in the Altiplano is still managed communally (Coppock et al., 2017). 


\subsection{Background on Native Forage Species of the Bolivian Altiplano}

Under current management practices, the herds of the poorest pastoralists are observed to be experience an accelerated productivity decline (Alcazar, Morales Sanchez, \& Rojas, 2003). The Food and Agriculture Organization of the United Nations [FAO] (FAO, 2005; Vera, 2006) reported birth rates of 50-60\% and death rates of $35-55 \%$ in Bolivian rural llama populations.

Low forage availability, particularly during the dry season (from May to November) is a recognized challenge for rural llama husbandry in Bolivia (Barreta et al., 2013; Fugal, Anderson, \& Roundy, 2010; Van Saun, 2006; Genin, Villca, \& Abasto, 1994; San Martin \& Bryant, 1989; Reiner, Bryant, Farfan, \& Craddock, 1987). Animals are more susceptible to parasitic infections during the dry season (Fugal et al., 2010) when forage availability is low, and the animals' immune system and overall health is weakened (Alandia, 2003). Alzérreca (1992) states that native Bolivian vegetation accounts for $98 \%$ of the llama diet, while the remaining $2 \%$ is sourced from cultivated fodder crops and crop residues. Ordonez (1994) found that llamas grazing in natural pastures in Ecuador consumed approximately $1.7 \mathrm{~kg}$ of dry matter (DM) daily per head. Stölzl, Lambertz and Gauly, (2015) noted that llamas raised in Central European grazing conditions had a DMI of $0.85 \%$ of BW. Alzérreca (1985) states that Bolivian Altiplano grazing lands produce an average DM yield of 400-800 kg/ha/year and estimates that the central Altiplano could support a carrying capacity of 7-21 ha/AU/year (Note 1 . AU $=1$ llama. Source: Alzérreca (1985)).

\subsection{Land-Use Pressure in the Bolivian Altiplano}

Agricultural land intensification is one of the most significant factors for land-cover change (Kim et al., 2014; Lambin et al., 2001). In the Bolivian Altiplano, the trend is agricultural intensification and expansion of quinoa cultivation (Chenopodium quinoa Willd.) (Felix \& Villca, 2009; Postigo et al., 2008). The Altiplano region of the Potosi Department is Bolivia's main quinoa producing area and also the area with the highest concentration of llamas, i.e. 762793 heads according to Fundación de Estudios Sociológicos [FUNDES] (2009). Between 2000 and 2013, quinoa production in Bolivia more than tripled in area under cultivation (Blajos, Ojeda, Gandarillas, \& Gandarillas, 2014). Despite this increase, the average yield per hectare has decreased (Blajos et al., 2014; Jacobsen, 2011) - cf. Figure 1. Quinoa parcels are often sporadically distributed and, increasing, natural pastures are put under quinoa cultivation. (Bonifacio et al., 2014; Martinez, 2014). Free grazing llamas will graze on quinoa plants as the fields do not have delimitated areas. This can result in disputes between quinoa producers and llameros, with the llamas being called 'thieves' and the pastors held accountable for the economic losses of the quinoa producers (Bonifacio et al., 2014). The expansion of the area under quinoa production in the Altiplano has seen acceleration with the increased mechanization and use of tractors by quinoa farmers (Healy, 2001). When natural pastures are converted to quinoa parcels, soil degradation is accelerated through erosion and the destruction of the native vegetation. The destruction of natural vegetation greatly undermines llama productivity, as the availability of already scarce forage plants is decreased. Pastoralists are forced to pasture their animals in further marginalized areas, further from the corrals and home (Blajos et al., 2014). Quinoa was traditionally cultivated alongside llama husbandry, with a long crop rotation and llama manure used as fertilizer and to conserve soil humidity - but this has changed drastically in the last decade (Fonte et al., 2014; Jacobsen, 2011). With the quinoa 'boom' in full swing, llama husbandry has lost its attractiveness to rural agropastoralists. Traditional agropastoralists are abandoning llama husbandry in favour of exclusively growing quinoa as a cash crop (Martinez, 2014). This has upset the equilibrium between crop and animal production in the delicate Altiplano ecosystem (Chura, 2009). The increase in conversion of natural pastures into cropland puts the availability of native forage plants and the traditional ecological knowledge (TEK) associated with llama husbandry and forage plants at risk, which can result in the disappearance of this knowledge (Signorini, Piredda, $\&$ Bruschi, 2009; Martin, 1995). The current literature surrounding native forage plant species of the Bolivian Altiplano contains little ethnobotanical knowledge of these plant species. Moreover, Vidaurre, Paniagua and Moraes (2006) estimated that only 3\% of ethnobotanical studies carried out in Bolivia concerned the ethnobotany of forage species. 


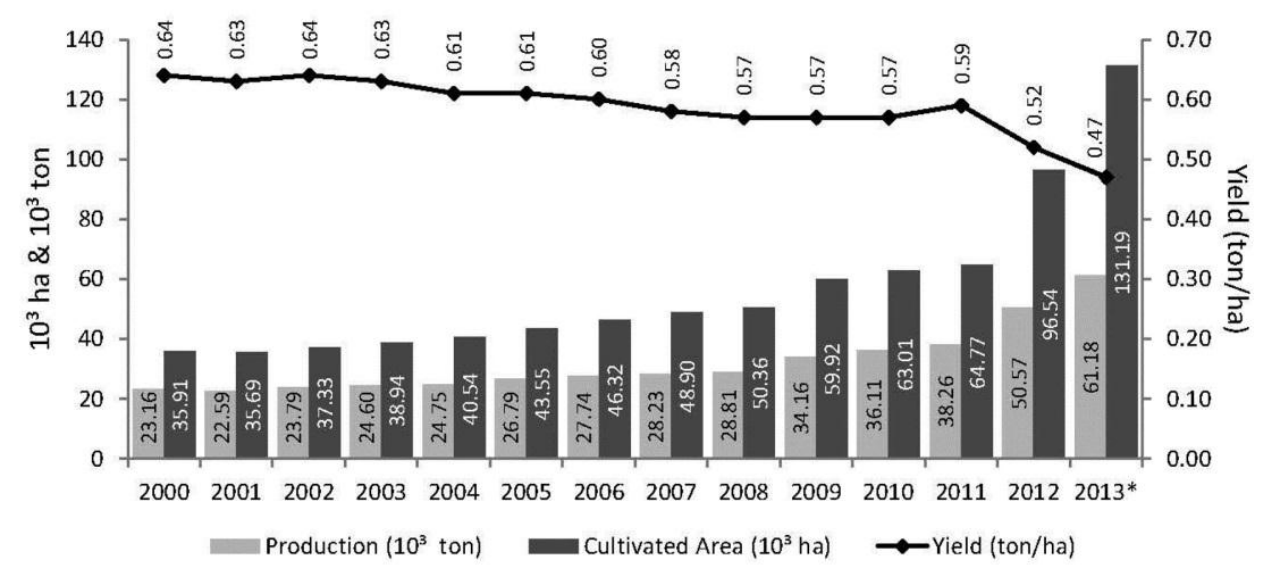

Figure 1. Quinoa production and expansion in Bolivia. Source: redrawn from Blajos et al., 2014

\section{Study Objective}

The study addresses the challenges and constraints of agropastoralism, and the associated traditional ecological knowledge (TEK) of native forage species in the Bolivian Altiplano. The study addresses the knowledge gap in llama husbandry in the Bolivian Altiplano, specifically the identification and perceived importance of native forage plants in natural pastures. The TEK of native plants for ethno-veterinarian controls was also studied.

\section{Methods}

\subsection{Study Area}

The study area encompassed three communities in the Province of Antonio Quijarro, Department of Potosi, Bolivia (Figure 2). Communities were chosen to have a similar population size and residents of all three communities derived their income from various degrees of agropastoralism. The Province accounts for 35\% of the entire Bolivian llama population (Instituto Nacional de Estatistica [INE], 2014). The study sites are characterised by an extremely low average annual rainfall $(277 \mathrm{~mm})$ and located at an average altitude of $4120 \mathrm{~m}$ a.s.l. (Table 1).

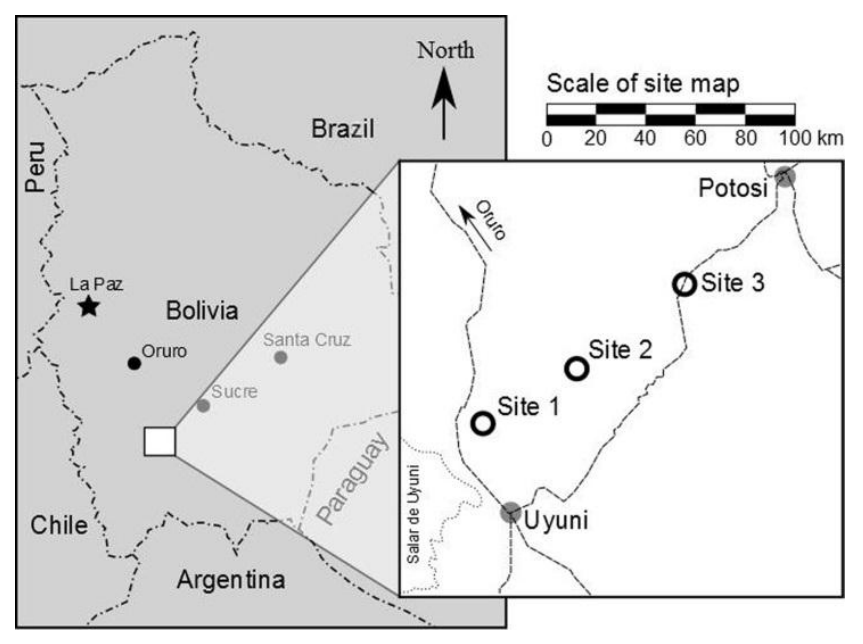

Figure 2. Map of the study area 
Table 1. Climatic and descriptive characteristics of study sites. Sources: adapted from personal correspondences (2014); SENAMHI (2014); and ZONISIG (2000)

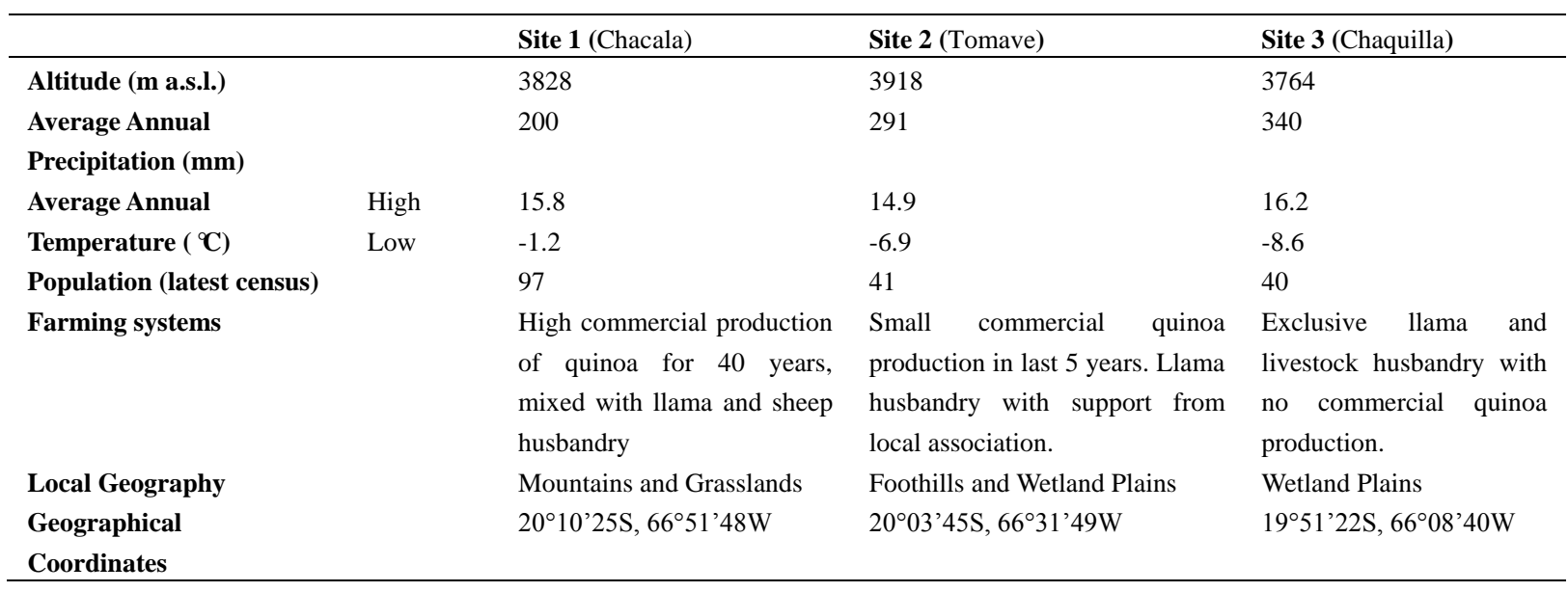

The climatic conditions and limited rainfall of the Department permit a vegetative growth period less than three months (Zonificacion Agroecologica y Socioeconomica, Departamento de Potosi, Bolivia [ZONISIG], 2000). The different United Nations Educational, Scientific and Cultural Organization [UNESCO] classes of native vegetation found in the Department are shown in Figure 3. The majority of the landscape is dominated by short, woody shrubs, tall bunchgrasses and perennial rhizomatous grasses and slow-growing perennials. UNESCO (1973, cited from ZONISIG, 2000) identified 409 plant species from 70 families in the Potosi Department (ZONISIG, 2000). The native vegetation consists primarily of species from the following families: Asteraceae (23\%), Poaceae (19\%), Fabaceae (5\%), Verbenaceae (3\%), Cactaceae (3\%), Mimosaceae (2\%), Solanaceae (2\%), the remaining $43 \%$ in other plant families (ZONISIG, 2000).
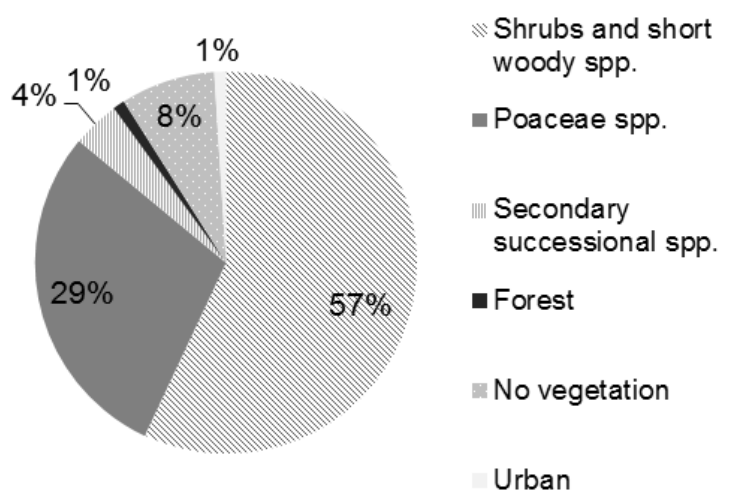

Figure 3. UNESCO classes of vegetation cover in Potosi Department. Source: ZONISIG, 2000

\subsection{Data Collection}

Data collection was carried out January to April 2014, during the wet season. Primary data was collected through an analytical survey developed in-situ. Following the first contact with study participants, the survey was developed with the help of three key informants from Site 1 whom also served as respondents for pilot testing the survey. The survey aimed to sample all llama-owning individuals at each of the three study sites to achieve maximum variation in the sample. In total, 41 respondents participated in the survey (Site 1: 12; Site 2: 15; Site 3: 14). After completing the survey with each respondent, a short interview on native forage plants was conducted each respondent was asked purposeful questions to consider their knowledge on native forage plants. The interviews were followed by a free listing exercise, where respondents were asked to name all known forage plants. Each time a respondent mentioned a plant during the survey, the interview and in the free listing exercise, the local plant names were recorded and noted as a citation to calculate the Relative Frequency of Citation (RFC) index. 


\subsection{Relative Frequency Citation (RFC) and Data Analysis}

The demographics and descriptive variables of the management practices of the study sites were recorded, and significant differences were measured between sites using a one-way analysis of variance (ANOVA). The Levene's test was performed to test for equal variances. When equal variances were assumed, the Scheffe post-hoc test was used, and when equal variances were not assumed, the Games-Howell post-hoc test was used to determine which sites differed significantly from one another.

To determine the subjective importance of forage species, the Relative Frequency of Citation (RFC) index was used (Ahmad et al., 2014; Signorini et al., 2009). The number of species cited by each respondent and the frequencies at which they were cited at each study site gives an idea of the TEK of forage plants in the area. By identifying the most frequently cited plants, it can be inferred that these species are indeed the most well-known and probably also the most important species (Ahmad et al., 2014; Estomba, Ladio, \& Lozada, 2006) for pastoral use.

As the RFC of a group does not take into consideration the frequency with which a respondent has cited a given plant, nor the total number of species cited by an individual, an adapted version of the RFC (per individual, RFCi) was also calculated to compare results.

In order to gain an understanding of the diversity of the forage plant community between sites, the Simpson Diversity Index (D) and Equitability (H) were calculated. The diversity indices and associated evenness were calculated for each individual, and then the average was taken to give a total diversity index for each site. The total and mean citations for each species at all three study sites were also calculated. By using quantitative measures in conjunction with qualitative measure and the context of the study sites, a useful picture of the ecology and ethnobotany at each site is produced.

The ethnobotanical datasets of native forage plants were analysed according to the statistical methods presented in Table 2 to obtain a measure of individual and local importance - i.e. site-specific - for each species to also elucidate the inter-site diversity of forage plants.

Table 2. Methods of statistical analyses applied

\begin{tabular}{|c|c|c|c|}
\hline & Application & Specification & Explanation \\
\hline \multirow{2}{*}{ 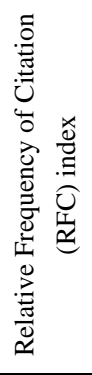 } & $\begin{array}{l}\text { To identify the most frequently cited plants for } \\
\text { each study site }\end{array}$ & $R F C=\frac{\mathrm{FC}}{\mathrm{N}}$ & $\begin{array}{l}\text { FC is the number of respondents who } \\
\text { mentioned a given species and } \mathrm{N} \text { is the } \\
\text { total number of respondents from the } \\
\text { site. }\end{array}$ \\
\hline & $\begin{array}{l}\text { To identify the most frequently cited plants for } \\
\text { each respondent/informant }\end{array}$ & $R F C_{i}=\frac{\mathrm{FC}_{\mathrm{i}}}{\mathrm{n}_{\mathrm{i}}}$ & $\begin{array}{l}\mathrm{FC}_{\mathrm{i}} \text { is the number of times an } \\
\text { individual (i) mentioned a given } \\
\text { species and } \mathrm{n}_{\mathrm{i}} \text { is the total number of } \\
\text { species citations recorded for this } \\
\text { respondent. }\end{array}$ \\
\hline \multirow{4}{*}{ 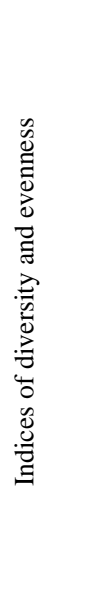 } & \multirow{4}{*}{$\begin{array}{l}\text { 1. the Simpson Diversity Index (D) and } \\
\text { 2. the Shannon Equitability Index (H) }\end{array}$} & $D_{i}=\frac{\sum_{j} m_{i j}\left(m_{i j}-1\right)}{M_{i}\left(M_{i}-1\right)}$ & \multirow{2}{*}{$\begin{array}{l}m_{i j} \text { is the total number of times that an } \\
\text { individual cited a given species }(j) \text { and } \\
M_{i} \text { is the total number of species cited } \\
\text { by this respondent. Afterwards, the } \\
\text { average was taken of the calculated } \mathrm{D}_{\mathrm{i}} \\
\text { values to give a species diversity for } \\
\text { the entire site, where } \mathrm{N} \text { is the total } \\
\text { number of respondents for the site. }\end{array}$} \\
\hline & & $D=\frac{\sum D_{i}}{N}$ & \\
\hline & & $H_{i}=\frac{\sum_{j}\left(\frac{m_{i j}}{M_{i}}\right) \times \ln \left(\frac{m_{i j}}{M_{i}}\right)}{\ln \left(M_{i}\right)}$ & $\begin{array}{l}\text { Symbols are identical to those used in } \\
\text { the calculation of } \mathrm{D}_{\mathrm{i}} \text {. The equitability } \\
\text { indicates how even the distribution of } \\
\text { species is for each respondent }\left(\mathrm{H}_{\mathrm{i}}\right)\end{array}$ \\
\hline & & $H=\frac{\sum H_{i}}{N}$ & $\begin{array}{l}\mathrm{H}_{\mathrm{i}} \text { was averaged to get an equitability } \\
\text { measure }(\mathrm{H}) \text { for the entire site. }\end{array}$ \\
\hline 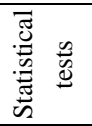 & $\begin{array}{l}\text { To analyse the inter-site differences with regard } \\
\text { to known forage species, a one-way analysis of } \\
\text { variance (ANOVA) was carried out }\end{array}$ & ANOVA & \\
\hline
\end{tabular}


To identify sites significantly different from each other with regard to knowledge of forage plants: 1. post-hoc Scheffe tests (assuming equal variances) and 2. Games-Howell tests Scheffe test (assuming unequal variances). Nb. Outliers, defined as a species mentioned by a sole individual and only on one occasion, were not included in the analysis of variance, but are presented in the base inventory list (see

Games-Howell test Appendix I)

The use of plants for ethno-veterinarian purposes was analysed using $X^{2}$ tests of $X^{2}$ test independence.

\section{Results}

\subsection{Site Differences}

Income derived from llama husbandry was reported at $17.91 \%$ on average from Site 1, 24.67\% from Site 2, and $36.07 \%$ from Site 3 - no statistical differences between sites was observed. As per the definition of agropastoralism (Jenet et al., 2016), all three sites fall into agropastoral systems as the inhabitants derive less than $50 \%$ of their income from animals and animal products.

Site 1 had the highest reported area of planted quinoa ( $\mu=10.33 \mathrm{ha}$ ), while Site 2 reported an average of $1.35 \mathrm{ha}$, and Site 3 had the lowest area of quinoa planted $(\mu=0.2 \mathrm{ha})$. Llama populations were reported to be decreasing at a significantly higher rate (p-value 0.001) at Site 1 than at Site 2 and Site 3 (p-value 0.007). Herd sizes reported from respondents were higher than those reported in previous studies. Livestock owners were asked what would be an ideal number of llamas in a herd in order to maintain a satisfactory livelihood. Mean ideal herd sizes of llamas per person were reported as 37.5 heads, 50.1 heads, and 40.9 heads at Sites 1, 2, and 3, respectively Table 3.

Table 3. Average herd size of llamas in Potosi Department and Ayopaya region, Bolivia

\begin{tabular}{|c|c|c|c|c|c|c|}
\hline & $\begin{array}{l}\text { From study } \\
\text { survey }\end{array}$ & $\begin{array}{l}\text { Markemann \& Valle } \\
\text { Zaráte (2010) }\end{array}$ & $\begin{array}{l}\text { Markemann } \\
(2007) \\
\end{array}$ & $\begin{array}{l}\text { Delgado } \\
(2003)\end{array}$ & $\begin{array}{l}\text { Nurnberg } \\
(\mathbf{2 0 0 5})\end{array}$ & $\begin{array}{ll}\text { FIDA et al. } \\
(1999)\end{array}$ \\
\hline Mean & 82.2 & 45.6 & 43.7 & 52.0 & 50.0 & 46.0 \\
\hline SD & 79.2 & 34.2 & 25.3 & 37.9 & 38.4 & - \\
\hline Range & $10-400$ & $5-153$ & $13-95$ & $6-254$ & $9-218$ & - \\
\hline $\begin{array}{l}\text { Number of herds/ } \\
\text { respondents }\end{array}$ & $41^{*}$ & 47 & $21 * *$ & 65 & 43 & $51,997 * * *$ \\
\hline
\end{tabular}

The number of citations of different ethnobotanical ecosystem categories varied among study sites. Post-hoc Scheffe tests revealed that the ecosystem of bofedales (wetlands); F $(2,38)=13.79$, p-value $=0.00$, was cited a significantly greater number of times at Sites $2(\mu=2.00, \sigma=1.134)$, and $3(\mu=1.57, \sigma=0.756)$ than at Site 1 $(\mu=0.25, \sigma=0.622)$. Post-hoc Scheffe tests revealed that espinas (spinose plants); F $(2,38)=10.448$, $\mathrm{p}$-value $=0.00$, were cited significantly more often at Site $1(\mathrm{M}=3.33, \mathrm{SD}=1.073)$ than at Sites $2(\mu=1.80, \sigma=1.373)$ and $3(\mu=1.21, \sigma=1.122)$. Similarly, post-hoc Scheffe tests revealed that herbaceous plants (pastos verdes); $(2,38)$ $=9.544, \mathrm{p}$-value $=0.00$, were cited a significantly higher number of times at Site $1(\mu=1.25, \sigma=0.965)$ than at Site $2(\mu=0.27, \sigma=0.458)$ and Site $3(\mu=0.29, \sigma=0.469)$.

\subsection{Time Inputs}

Livestock owners at Site 1 dedicated significantly more time to their animals than at Site 2 (p-value 0.000) and at Site 3 (p-value 0.000) in the wet season which runs from November - May. This is the same time that quinoa is planted, and the quinoa is harvested in April or May. During the wet season at site 1, the llamas need to be brought out to pasture and kept the entire day so as to make sure they do not enter quinoa plots and graze on the 
plants. The pastors employed were always family members at Sites 2 and 3, while at Site 1,75\% of the respondents used family members as pastors; $16 \%$ hired salaried pastors, and $8 \%$ employed the Partida system, where the livestock owner and the hired pastor split the llama products as a form of payment. The amount of time input required was stated as a limiting factor by $59 \%$ of the respondents at Site 1, while it was not mentioned as a problem at Sites 2 and 3, as the animals are allowed to graze freely throughout the year.

\subsection{Native Pasture Access \& Use}

Respondents across all three study sites stated that a single llama needs, on average 4.4 ha of natural pasture land in order to ensure the animal's wellbeing. There were some variations among sites, but no statistically significant differences. Most of the respondents in all three study sites stated that they had access to natural pasture lands for their animals to graze (Table 4); however, reported access to natural pastures was slightly lower at Site 1 . The most common limitation to ensuring sufficient pasture land at Site 1 was that there was no land available for the animals' to graze upon, as it was in use for quinoa production. At Site 3, respondents also reported a low level of perceived sufficient pasture land available $(\mu=0.414)$. However, respondents stated overstocking of animals and overgrazing of the available pasture lands as reasoning to their answers. Respondents at Site 1 reported the significantly lower perception of secure, long-term access to pasture lands.

Table 4. Native Pasture Use \& Access

\begin{tabular}{|c|c|c|c|c|}
\hline & & Mean Site 1 & Mean Site 2 & Mean Site 3 \\
\hline Access to pasture land & $0=\mathrm{NO}, 1=\mathrm{YES}$ & 0.75 & 1.00 & 1.00 \\
\hline Secure, long-term access & $0=\mathrm{NO}, 1=\mathrm{YES}$ & $* * 0.08$ & 0.80 & 0.85 \\
\hline Sufficient pasture land & $0=\mathrm{NO}, 1=\mathrm{YES}$ & $* * 0.00$ & 0.80 & 0.42 \\
\hline Pasture Requirement & ha required for a single llama & 5.40 & 4.25 & 3.19 \\
\hline
\end{tabular}

\subsection{Manure}

All respondents at the three study sites used llama manure as an agricultural fertilizer. All respondents were aware of the agricultural benefits of manure applications, i.e. that it is rich in nutrients and enhances water-holding capacity and soil aeration. Manure was generally harvested from corrals or communal latrines latrines and applied every 2 years when the soil was tilled, prior to planting. A metric ton of fresh llama manure is sold for on average BOB 193.95. Manure is sold to neighbours in the same community, or to nearby communities. According to the United States Department of Agriculture [USDA], llamas generate an average of $150 \mathrm{~kg}$ of manure a month (USDA, 2008). This results in a potential profit of BOB 32 per llama per month. With an average herd size of 82.2 heads (from current study), a theoretical monthly profit of BOB 2630.40 (equivalent to USD 380.97 on $5^{\text {th }}$ May 2018) can be generated solely from the sale of llama manure. The results from the study showed that the amount of manure sold (intra and inter-communities) was found to differ significantly among study sites; F $(2,38)=17.78$, p-value $=0.00$. Post-hoc Games-Howell tests revealed that Site $3(\mu=1.00$, $\sigma=0)$ sold significantly higher amounts of manure than Site $1(\mu=0.17, \sigma=0.389)$ and Site $2(\mu=0.4, \sigma=0.508)$ with a p-value of 0.000 and 0.001 , respectively.

\subsection{Future Outlook of Llama Husbandry}

Livestock owners were asked if they would like to continue with llama husbandry as a livelihood. Respondents at Site 1 showed a significantly lower interest in continuing with llama husbandry than at Sites 2 and 3 (p-value 0.013 , and p-value 0.017 respectively). At the time of the study, 33\% of respondents at Site 1 were planning on slaughtering their entire herd at the beginning of the dry season (May) because the work involved was too demanding for the amount of income it generated, and the dwindling amount of natural pastures in the area.

\subsection{Ethnobotany of Native Forage Plants}

A total of 59 different plants (including ethnobotanical groups) were cited by respondents from all study sites. Based on the botanical identification, a total of 54 individual species (in some cases sub-species) were identified, belonging to 44 genera and 18 families. When it was impossible to identify the exact species the annotation 'cf.' was used. The five main ethnobotanical groups of plants stated by respondents were: espinas (spinose plants), leñas/tolas (shrubs), pastos verdes (herbaceous plants), bofedal (wetland plants), and pajas/ichu (grasses). Some informants recognized each of these groups as a single species (ethno-species), while others further defined specific vernacular names within each classification. Vernacular names are sometimes given to an entire class of 
plants, rather than a specific species (Villagrán \& Castro, 2004). See the base inventory list in Appendix I for a complete description of all cited forage plants and classes of plants. The plant families most frequently mentioned by informants were: Poaceae (22.2\%; 9 species, 123 citations), Fabaceae $(20.9 \% ; 7,116)$, Asteraceae $(20.4 \% ; 13$, $113)$ and Malvaceae $(8.7 \% ; 2,48)$ - Table 5).

Table 5. Botanical families most frequently mentioned by respondents across all sites of this study compared to findings in ZONISIG (2000). Values listed in percent of all responses

\begin{tabular}{lll}
\hline Botanical Family & Current Study $(\%)$ & ZONISIG Study $(\%)$ \\
\hline Asteraceae & 12.4 & 23 \\
Poaceae & 13.7 & 19 \\
Fabaceae & 12.8 & 5 \\
Amaranthaceae & 2.8 & - \\
Malvaceae & 5.3 & - \\
Lamiaceae & 2.4 & - \\
Solanaceae & 2.1 & - \\
Verbenaceae & 1.5 & - \\
Cactaceae & $<1$ & - \\
Apiaceae & $<1$ & - \\
Campanulaceae & 2.6 & - \\
Pteridaceae & 1.9 & - \\
Juncaceae & 1.2 & - \\
Rosaceae & $<1$ & - \\
Loasaceae & $<1$ & - \\
Linaceae & $<1$ & - \\
Ephedraceae & $<1$ & - \\
Amaryllidaceae & $<1$ & - \\
\hline
\end{tabular}

A total of 909 citations were recorded from interviews with a total of 41 respondents across all three study sites. Four of the mentioned forage plants (Tables 5) were cultivated crops: mint, barley, alfalfa and flax. Crop residues of broad beans from home-gardens and quinoa residues were also used as fodder. Quinoa crop residues (hipi de quinoa) were most often used as fodder by respondents at Site 1 ( $75 \%$ of respondents). The remaining 48 plants are all wild, native plant species.

A total of 25 plants were reported to be of additional medicinal value, while 9 were cited to be used for ethno-veterinarian purposes (See Appendix I and Table 6). Some species were reported to be toxic to livestock (6 species) - Appendix I.

The forage plants mentioned by respondents were distributed across local ecosystems - Figure 4. A total of seven ecosystem classes were mentioned in the local language. Translated, a bofedal is a type of seasonal wetland where hydrophilic plants can be found year round. The local ecosystem classification of pampa was reported to contain the highest concentration of forage plants. Pampa can be translated from Quechua to English as plains, or grasslands.

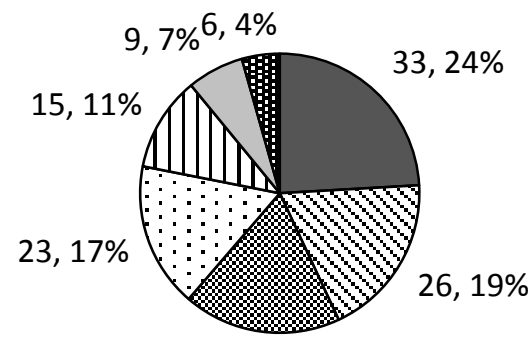

$25,18 \%$

\author{
$\square$ Pampa \\ Q Pampa Alta \\ Pampa Baja \\ $\square$ Quebrada \\ (ravine)
}

Figure 4. Local distribution of forage plants (per cent of species) to ecosystem classes according to respondents 


\subsection{Relative Frequency Citation of Forage Species}

The RFC and $\mathrm{RFC}_{\mathrm{i}}$ were calculated as a basis for a comparative ranking of forage species (Table 6), in order to identify the most important species at each study site. A complete table of the RFC and $\mathrm{RFC}_{\mathrm{i}}$ indices can be found in Appendix II. Sites 2 and 3 had similar rankings of $\mathrm{RFC}$ and $\mathrm{RFC}_{\mathrm{i}}$, while Site 1 differed more from the other two study sites (Figure 5; Table 7). The ethnobotanical groups of spinose plants (espinas), shrubs (leñas/tolas) and grasses (paja/ichu) were ranked among the top five categories of forage species across all three study sites. Sites 2 and 3 ranked the ethnobotanical group of wetland species (bofedales) much higher than Site 1 . Sites 2 and 3 also ranked cultivated crops, such as mint and barley, higher than Site 1. However, Site 1 ranked crop residues of quinoa among the top 10 forage plants, whereas Sites 2 and 3 did not. Significant differences in the number of times a specific ethno-species was mentioned as a forage plant were found between sites (see Table 8).

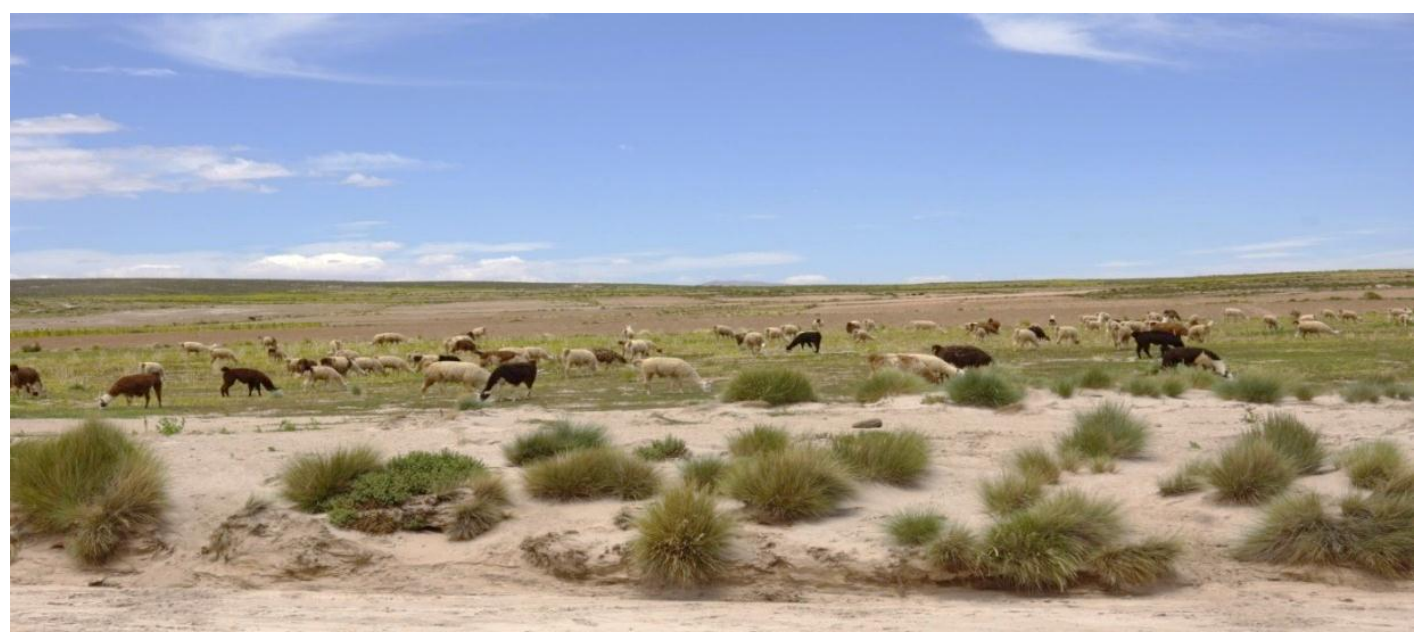

Figure 5. A herd of llamas grazing on natural vegetation with quinoa plots (chacras) in the background at Site 1.

Photo: M. Sørensen (2014)

Table 6. Comparative ranking of forage plants based on mean Relative Frequency Citation, $\mathrm{RFC}_{\text {and }} \mathrm{RFC}_{\mathrm{i}}$ (see text). Only the two highest ranks of vegetation categories and the four highest ranks of individual species are shown. Estimated values of RFC and $\mathrm{RFC}_{\mathrm{i}}$ are shown in square brackets

\begin{tabular}{|c|c|c|c|c|c|c|c|}
\hline \multirow[t]{2}{*}{ Rank } & \multicolumn{2}{|c|}{ Site 1} & \multicolumn{2}{|c|}{ Site 2} & \multicolumn{2}{|c|}{ Site 3} & \multirow[t]{2}{*}{ PRA Ranking } \\
\hline & RFC & $\mathbf{R F C}_{\mathbf{i}}$ & RFC & $\mathbf{R F C}_{\mathbf{i}}$ & RFC & $\mathbf{R F C}_{\mathbf{i}}$ & \\
\hline \multicolumn{8}{|c|}{ Ranking of vegetation categories } \\
\hline 1 & $\begin{array}{l}* \text { Spinose (Espinas) } \\
* \text { Shrubs (Leñas/Tolas) } \\
{[1.0]}\end{array}$ & $\begin{array}{l}* \text { Spinose (Espinas) } \\
{[0.115]}\end{array}$ & $\begin{array}{l}\text { *Wetlands (Bofedal) } \\
{[1.0]}\end{array}$ & $\begin{array}{l}\text { *Shrubs (Leñas/Tolas) } \\
{[0.123]}\end{array}$ & $\begin{array}{l}{ }^{*} \text { Grasses (Ichu/Paja) } \\
{[1.0]}\end{array}$ & $\begin{array}{l}{ }^{*} \text { Grasses (Ichu/Paja) } \\
{[0.158]}\end{array}$ & \\
\hline 2 & $\begin{array}{l}\text { *Herbaceous Plants } \\
\text { (Pastos verdes), } \\
\text { *Grasses (Ichu/Paja) } \\
{[0.83]}\end{array}$ & $\begin{array}{l}\text { *Shrubs (Leñas/Tolas) } \\
{[0.084]}\end{array}$ & $\begin{array}{l}* \text { Shrubs (Leñas/Tolas) } \\
* \text { Grasses (Ichu/Paja) } \\
{[0.93]}\end{array}$ & $\begin{array}{l}\text { *Wetlands (Bofedal) } \\
{[0.113]}\end{array}$ & $\begin{array}{l}\text { *Wetlands (Bofedal) } \\
\text { *Shrubs (Leñas/Tolas) } \\
{[0.93]}\end{array}$ & $\begin{array}{l}\text { *Shrubs (Leñas/Tolas) } \\
{[0.143]}\end{array}$ & \\
\hline \multicolumn{8}{|c|}{ Ranking of individual species } \\
\hline 1 & $\begin{array}{l}\text { Tarasa tenella (Cav.) } \\
\text { Krapov. } \\
{[1.0]}\end{array}$ & $\begin{array}{l}\text { Tarasa tenella (Cav.) } \\
\text { Krapov. } \\
{[0.111]}\end{array}$ & $\begin{array}{l}\text { **Medicago sativa } \mathrm{L} \text {. } \\
\text { Festuca orthophylla } \\
\text { Pilg }[0.67]\end{array}$ & $\begin{array}{l}\text { *Medicago sativa } \mathrm{L} \text {. } \\
{[0.072]}\end{array}$ & $\begin{array}{l}\text { Lobelia oligophylla } \\
\text { (Wedd.) Lammers } \\
\text { Astragalus } \\
\text { garbancillo Cav. } \\
{[0.64]}\end{array}$ & $\begin{array}{l}\text { Lobelia oligophylla } \\
\text { (Wedd.) Lammers } \\
{[0.069]}\end{array}$ & $\begin{array}{l}\text { Festuca orthophylla } \\
\text { Pilg. }\end{array}$ \\
\hline 2 & $\begin{array}{l}\text { Tagetes multiflora } \\
\text { Kunth } \\
{[0.92]}\end{array}$ & $\begin{array}{l}\text { Chondrosum cf. } \\
\text { simplex (Lag.) Kunth } \\
{[0.069]}\end{array}$ & $\begin{array}{l}\text { **Hordeum vulgare } \mathrm{L} \text {. } \\
\text { Parastrephia } \\
\text { lepidophylla (Wedd.) } \\
\text { Cabrera }\end{array}$ & $\begin{array}{l}\text { **Hordeum vulgare } \mathrm{L} \text {. } \\
{[0.064]}\end{array}$ & $\begin{array}{l}\text { Parastrephia } \\
\text { lepidophylla } \\
\text { Clinopodium } \\
\text { bolivianum (Benth.) }\end{array}$ & $\begin{array}{l}* * \text { Medicago sativa } \mathrm{L} \text {. } \\
{[0.045]}\end{array}$ & $\begin{array}{l}\text { Parastrephia } \\
\text { lepidophylla (Wedd.) } \\
\text { Cabrera }\end{array}$ \\
\hline & & & {$[0.53]$} & & Kunth & & \\
\hline
\end{tabular}




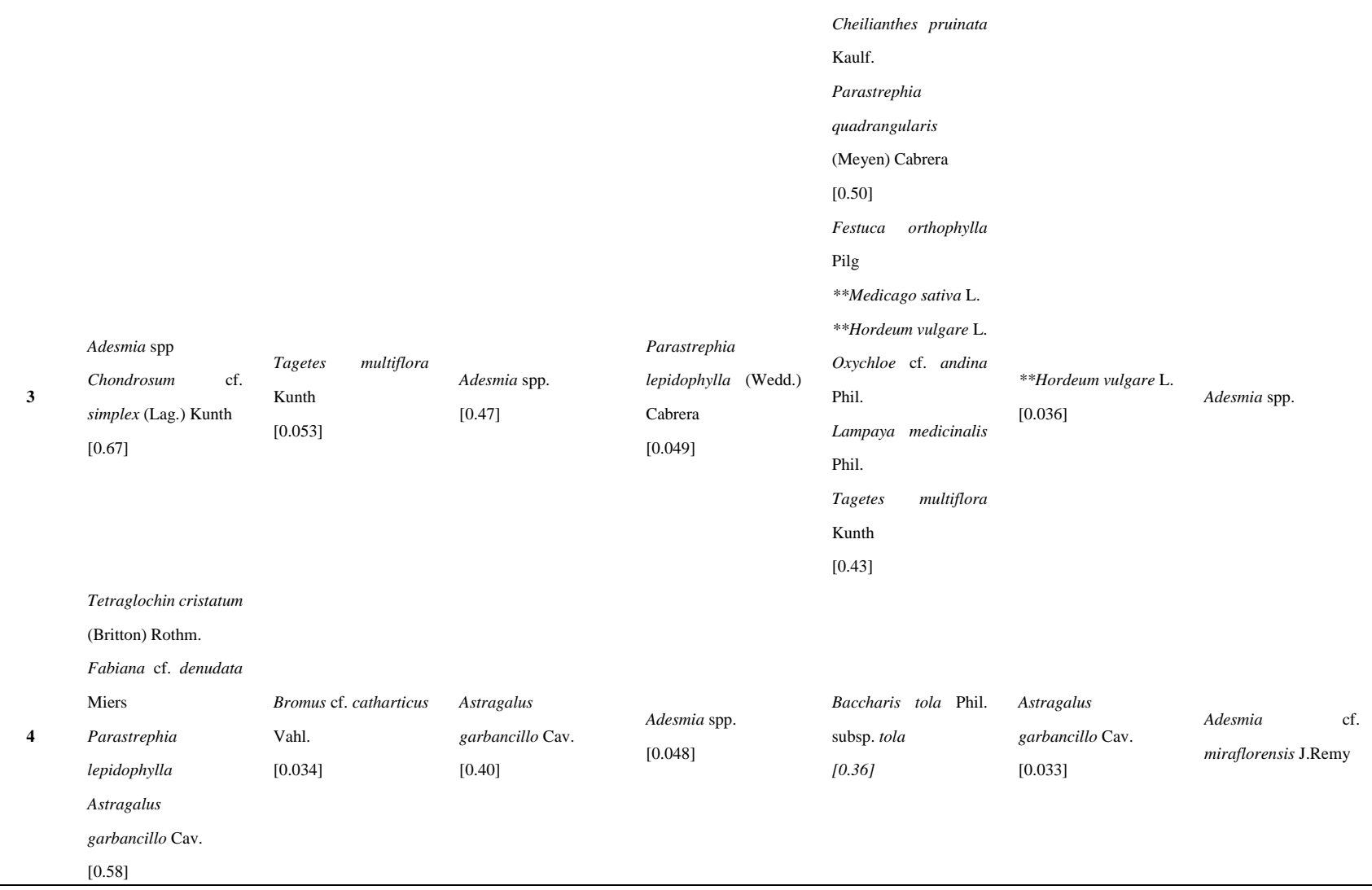

*ethnobotanical group, **cultivated crop

Table 7. Reported ethno-veterinarian plant species and use at the three sites (\% of respondents who report use)

\begin{tabular}{|c|c|c|c|c|c|c|}
\hline \multirow[t]{2}{*}{ Plant Species } & \multirow{2}{*}{$\begin{array}{l}\text { Vernacular } \\
\text { name }\end{array}$} & \multicolumn{3}{|c|}{$\begin{array}{c}\text { Percentage of Respondents who } \\
\text { Reported Use (\%) }\end{array}$} & \multirow{2}{*}{$\begin{array}{c}\text { Average } \\
(\%)\end{array}$} & \multirow[t]{2}{*}{ Use } \\
\hline & & Site 1 & Site 2 & Site 3 & & \\
\hline Tagetes multiflora Kunth & Suico & 83.3 & 26.7 & 42.9 & 48.8 & $\begin{array}{l}\text { Herbal infusion used to treat diarrhea, } \\
\text { constipation, and bloating }\end{array}$ \\
\hline $\begin{array}{l}\text { Clinopodium bolivianum } \\
\text { (Benth.) Kunth }\end{array}$ & Muña & 33.3 & 33.3 & 50 & 39 & $\begin{array}{l}\text { Herbal infusion used to treat diarrhea, } \\
\text { constipation, and bloating }\end{array}$ \\
\hline Mentha spp. & Hierbabuena & 0 & 26.7 & 14.3 & 14.6 & $\begin{array}{l}\text { Herbal infusion used to treat diarrhea, } \\
\text { constipation, and bloating }\end{array}$ \\
\hline Senecio cf. nutans Sch.Bip. & Chachacoma & 25.0 & 0 & 0 & 7.3 & Herbal infusion used to treat bloating \\
\hline Spinose plants & Espinas & 0 & 6.7 & 0 & 2.4 & $\begin{array}{l}\text { Herbal infusion of } 7 \text { different spinose } \\
\text { plants to cure all illness }\end{array}$ \\
\hline Linum usitatissimum $\mathrm{L}$. & Linaza & 0 & 6.7 & 0 & 2.4 & Herbal infusion for purgative effects \\
\hline $\begin{array}{l}\text { Xenophyllum cf. popusum } \\
\text { (Phil.) V.A. Funk }\end{array}$ & Pupusa & 0 & 6.7 & 0 & 2.4 & Herbal infusion to treat diarrhea \\
\hline $\begin{array}{l}\text { Fabiana cf. denudata } \\
\text { Miers }\end{array}$ & Tara tara & 2.4 & 0 & 0 & 2.4 & $\begin{array}{l}\text { Pomace made with leaves to treat } \\
\text { fractures/broken bones }\end{array}$ \\
\hline
\end{tabular}

\subsection{Inter-Site Diversity of Forage Plants}

No significant differences were found between sites for the calculated Simpson index of diversity for plant citations (Table 8). A one-way ANOVA of equitability $\left(\mathrm{H}_{\mathrm{i}}\right)$ in citations between the sites did reveal significant differences; with $\mathrm{P}<0.05$. Post-hoc Scheffe tests revealed that Site $1(\mathrm{H}=0.9379, \mathrm{SD}=0.01034)$ had significantly lower equitability than Site $3(\mathrm{H}=0.9522, \mathrm{SD}=0.01877)$. These results show that respondents at Site 1 mentioned a significantly wider variety of species than at Sites 2 and 3; with the citations from respondents at site 3 being the less varied. 


\subsection{Inter-Site Variation of Native Forage Plant Use}

The variation with respect to the number of citations of native forage plant species and categories between sites is shown in Table 8. The number of citations of different ethnobotanical ecosystem categories as apparent from the average FCi-values varied among study sites. Post-hoc Scheffe test for the bofedal ecosystem $(\mathrm{P}<0.001)$ was cited a greater number of times at Sites 2 and 3 than at Site 1. Post-hoc Scheffe tests revealed that espinas $(\mathrm{P}<0.001)$, were cited more often at Site 1 than at Sites 2 and 3. Similarly, post-hoc Scheffe tests divulged that pastos verdes $(\mathrm{P}<0.001)$, were cited more at Site 1 (Figure 6) than at Sites 2 and 3.

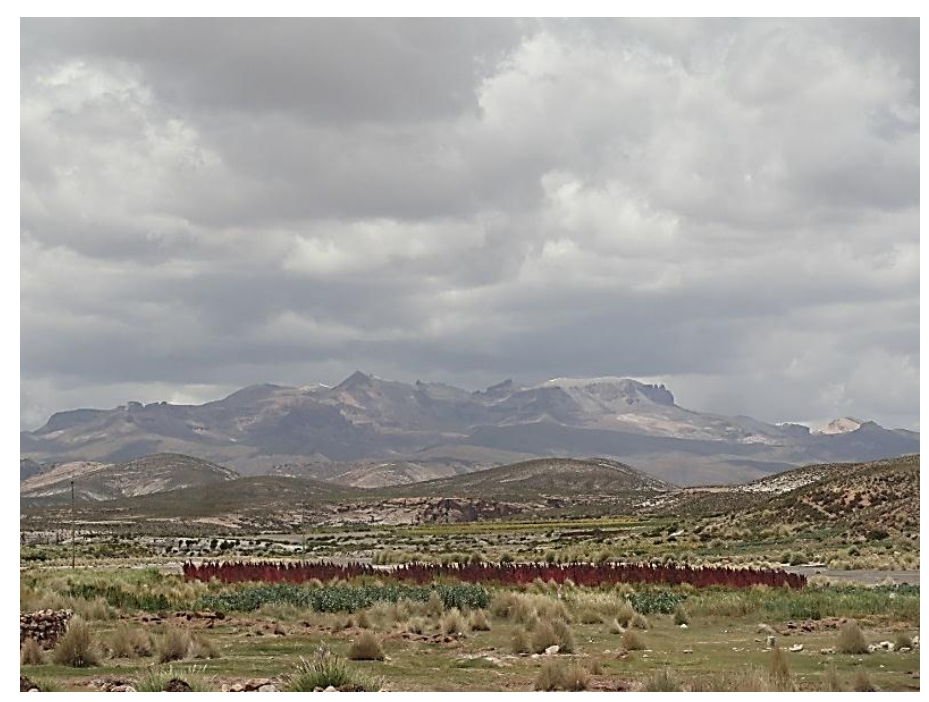

Figure 6. View of quinoa and llama grazing areas at study site 1: Chacala, Potosi Region, Bolivia.

Photo: S.J. D’Apollonia (2014)

Significant differences in the number of times a specific ethno-species was mentioned as a forage plant were also found between sites (Table 5). Post-hoc Games-Howell tests were used to analyse for the following species to determine where exactly the differences between sites lie. Respondents at Site 3 did not mention Adesmia spp. as forage species while mentioned at Site 1 (mean=0.92, SD=0.900) (Figure 7) and Site 2 (mean=1.07, SD=1.486). Upon observation Adesmia spp. were found to be present at Site 3, although the plants were mainly found in the foothills (quebradas) and not the principal grazing area of the wetlands (bofedal). Lobelia oligophylla (Wedd.) Lammers, F $(2,38)=5.426$, p-value $=0.008$, was mentioned more often at Site 3 (mean=1.14, SD=1.099) than at Sites 1 (mean=0.25, $\mathrm{SD}=0.452$ ) and 2 (mean=0.33, $\mathrm{SD}=0.617$ ). Lampaya medicinalis $\mathrm{Phil}$., $\mathrm{F}(2,38)=4.22$, $\mathrm{p}$-value $=0.022$, was cited as a forage plant a greater number of times at Site 3 (mean $=0.57, \mathrm{SD}=0.852$ ) than at Sites 1 (mean=0.17, $\mathrm{SD}=0.389$ ) and 2 (mean=0.00, $\mathrm{SD}=0.00$ ). Bromus cf. catharticus Vahl., $\mathrm{F}(2,38)=3.912$, $\mathrm{p}$-value $=0.029$, was cited significantly less frequently as a forage species at Site 3 (mean $=0.07, \mathrm{SD}=0.267$ ) than at Sites 1 (mean=0.92, $\mathrm{SD}=1.165$ ) and 2 (mean=0.33, $\mathrm{SD}=0.724)$. While species such as; Chondrosum cf. simplex (Lag.) Kunth, Opuntia cf. soehrensii Britton \& Rose, Tarasa tenella (Cav.) Krapov. and Tagetes multiflora Kunth were all mentioned a significantly greater number of times at Site 1 than at Sites 2 and 3. 


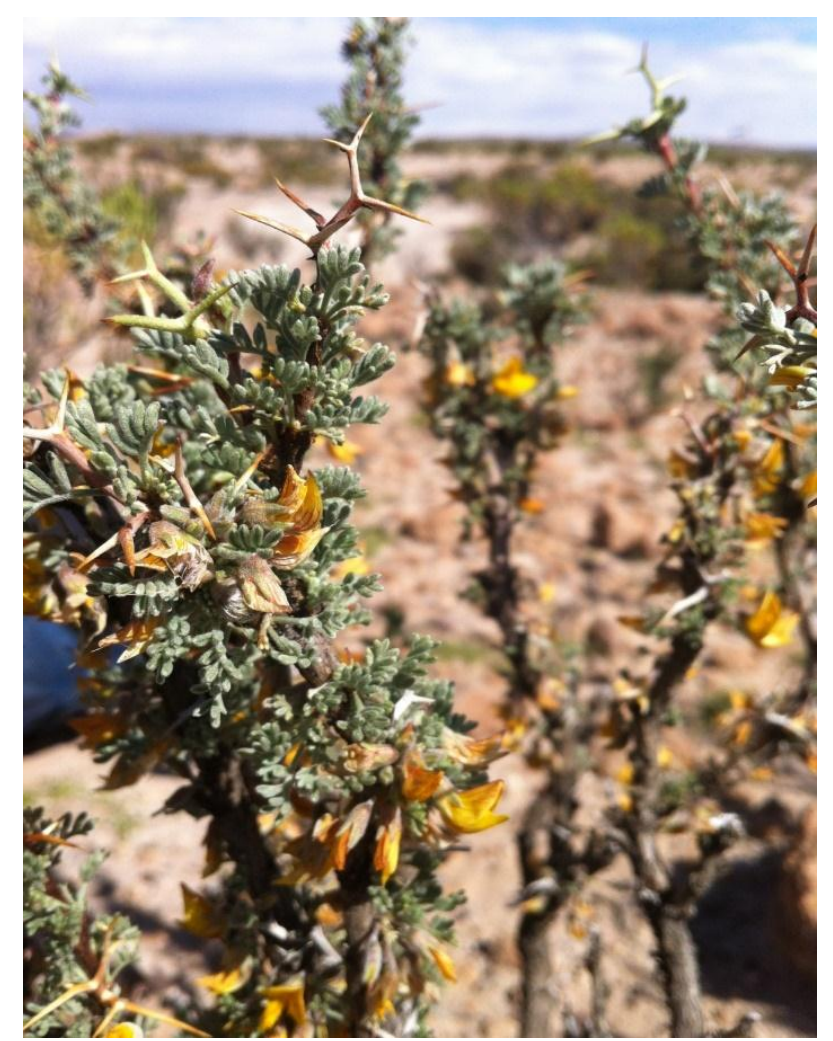

Figure 7. Native forage plant at study site 1; añawaya (Adesmia sp.). Photo: S.J. D’Apollonia (2014)

Table 8. Ethnobotanical citations and associated diversity indices for each of the three sites. Pairwise comparisons between sites were done for the diversity and equitability measures using post hoc Scheffe tests. Within each row, estimates marked with the same letter $(a, b)$ are not significantly different at the $5 \%$ probability level

\begin{tabular}{llll}
\hline & Site 1 & Site 2 & Site 3 \\
\hline Total number of citations & 352 & 304 & 253 \\
Total number of different species cited & 41 & 39 & 33 \\
Mean number of citations (per respondent) & 29 & 20 & 18 \\
Median number of citations & 26 & 20 & 18 \\
Simpson Index of Diversity (D) & $0.109^{\mathrm{a}}$ & $0.139^{\mathrm{a}}$ & $0.127^{\mathrm{a}}$ \\
Equitability (H) & $0.937^{\mathrm{a}}$ & $0.945^{\mathrm{ab}}$ & $0.952^{\mathrm{b}}$ \\
\hline
\end{tabular}

\section{Discussion}

\subsection{Future Outlook of Llama Husbandry in the Bolivian Altiplano}

The study sites were chosen to include agropastoralists pursuing different livelihood strategies involving livestock (llama) husbandry and quinoa production (Figure 8). Site 1 was chosen as a representation of a village with a high degree of quinoa production and a low degree of llama husbandry. Site 2 was chosen to represent a village with a balance of both llama and quinoa production, and Site 3 was chosen as a community that exclusively practised llama husbandry. The results of the socioeconomic descriptions from the survey confirm these general village characterisations. Respondents at Site 1 planted a significantly greater area of quinoa in the community ( $\mu=10.33 \mathrm{ha}$ ) in comparison to Sites $2(\mu=1.35$ ha) and $3(\mu=0.2$ ha). Respondents at Site 1 also placed significantly higher importance on quinoa production than livestock husbandry. It was observed that Site 3 rated livestock husbandry as being of significantly higher importance than the other two study sites. Furthermore, the reported income derived from llama husbandry across study areas reflects the accurate description of the study sites, with Site 3 deriving the most income from llama husbandry $(\mu=36.07 \%)$, and Site 
1 deriving the least $(\mu=17.91 \%)$. The rejection of the null hypothesis that all study sites are equal in their livelihood pursuits is of crucial importance in order to compare the impact of land-use pressure on rural llama husbandry.

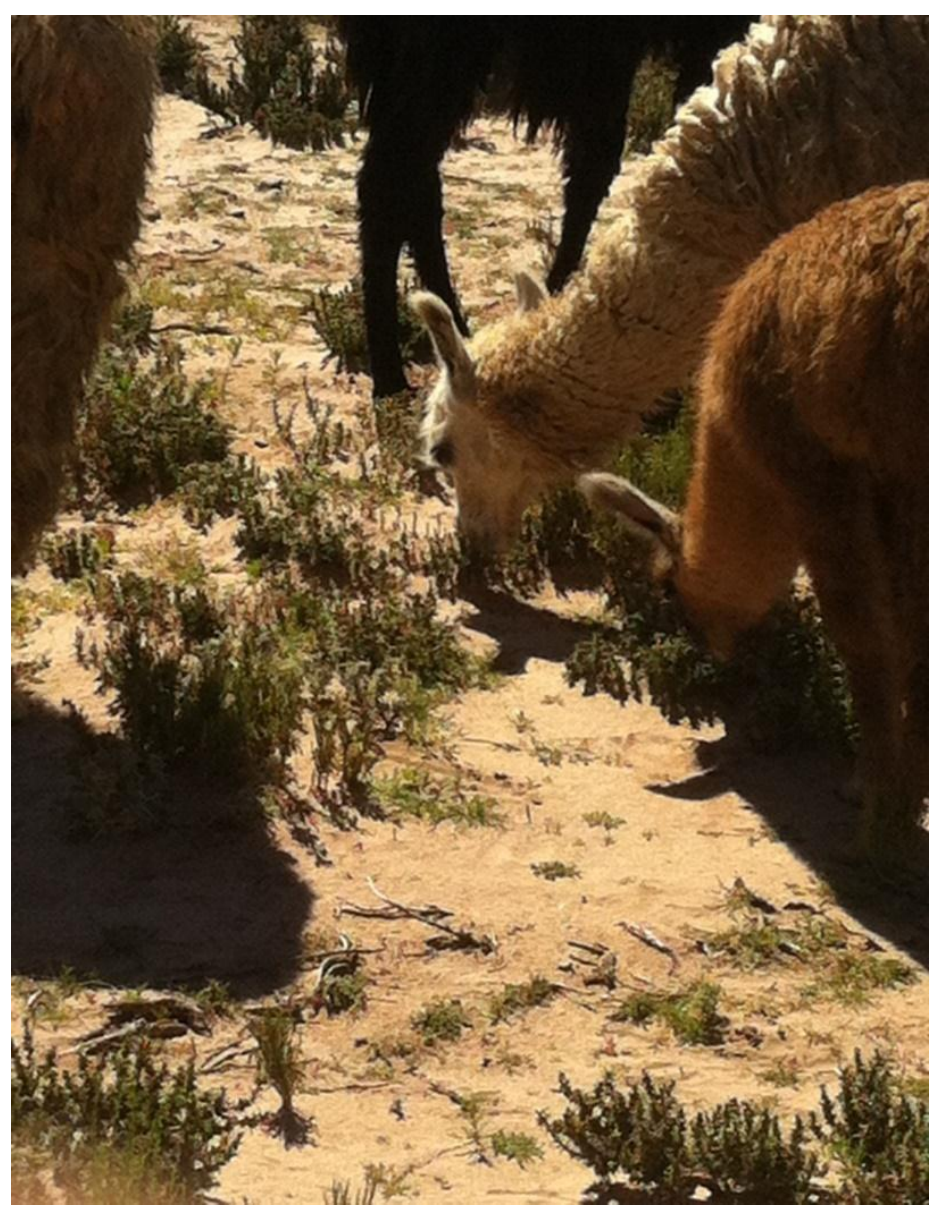

Figure 8. Llamas grazing on native forage plants. Study Site 1: Chacala, Potosi Region, Bolivia.

Photo: S.J. D’Apollonia (2014)

Respondents at Site 1 stated that their llama populations were, on average, in decline. This contrasts findings at Sites 2 and 3, where respondents stated that their llama populations were stable or increasing. This is a very important finding, in that it confirms that the future of llama husbandry is at risk in areas where there is a perceived lack of pasture. Responses from the analytical survey on the future forecasts for llama husbandry at Site 1 show that only four of the pastoralists interviewed said they would continue with llama husbandry the following year. From surveys, interviews and focus groups with llameros at Site 1, the greatest constraint in llama husbandry was a lack of pasture caused by land-use competition with quinoa producers. As quinoa production increases, through expanding cropland, native pastures are disappearing (according to pers. comm. with local villagers, 2014; Bonifacio, 2014; Jacobsen, 2011). This trend is slowly being recognized by altiplano residents as an impending threat to traditional livelihoods such as llama husbandry.

\subsection{Forage Plants in Natural Pastures}

The present study offers a good basis for further investigation of the native forage plant community in the Bolivian Altiplano. Most of the plants (84.58\%) reported as forage species were found in the pampa ecosystem (including pampa alta and pampa baja). However, the bofedal ecosystem was mentioned a significantly greater number of times at Sites 2 and 3. This could signify that respondents at Sites 2 and 3 placed higher importance on the forage plant species sustained in a bofedal ecosystem. All study sites mentioned shrubs (leñas/tolas) with a high RFC ranking. This shows that these native shrubs species are considered a vital component of $L$. glama diets in natural pastures, which is also in agreement with previous studies (Fugal et al., 2010; Bryant \& Farfan, 1984). 


\subsection{Ethnobotany and TEK of Native Forage Plants}

The $\mathrm{RFC}_{\mathrm{i}}$ takes into consideration the frequency of citations for each individual respondent rather than the citations across an entire group of respondents; we therefore consider $\mathrm{RFC}_{\mathrm{i}}$ a more useful index. We did not perform any analysis of correlations to determine why there were variances between RFCi, and the frequency of citations was only analysed on an inter-site level. Further analysis to determine factors such as age, gender, time at a pasture that may correlate with TEK could be carried out.

The ethnobotanical importance of forage species must not be neglected when developing management plans for natural pastures. Many forage species cited by respondents are very slow-growing and, for example, Yareda (Azorella compacta Phil.), found in bofedales, is estimated to grow $1.5 \mathrm{~cm}$ per year (Kleier \& Rundel, 2004), while tola (shrub) species are known to be of particularly slow growth (ZONISIG, 2000). Management plans of natural pastures should incorporate the slow growth rates of these native forage species, especially if they are rated with a high RFC.

\section{Conclusion}

Management of natural pastures must incorporate results from studies which detail the most important forage species from an ethnobotanical perspective and consider findings from studies which employ PRA methods. These results can also be applied to more quantitative studies with detailed counts of the abundances and availability of native forage species in natural pastures by performing controlled plot sampling of the natural landscape in order to determine native forage species abundances and availability. The conflict between llameros and quinoa producers arises because of the direct competition for land use. This case study reveals that the expected costs of time and labour investment outweigh the expected benefits of llama husbandry. The current market price of llama products is too low for rural llama husbandry to remain competitive with other rural livelihood options. Secondary, value-added llama products such as manure may provide an added economic incentive for rural peoples to pursue llama husbandry. Challenges are sometimes case-specific, as in the case of Site 1 which mentioned access to pasture land as the greatest challenge, while access to quality forage plants throughout the year (specific deficits reported from June - August) was a common constraint across all study sites. Parallel livestock and crop systems in areas where llama and quinoa production are in direct competition were observed and explored in this study. Both livelihoods have the ability to be mutually beneficial if land-use conflicts are addressed. The need for re-establishing a balanced and integrated quinoa-llama production system with adequate forage availability in the Bolivian Altiplano is of crucial importance for ensuring long-term sustainability for rural livelihoods and the environment.

\section{Conflict of interest statement}

None.

\section{References}

Ahmad, M., Sultana, S., Fazl-I-Hadi, S., Ben Hadda, T., Rashid ,S., Zafar, M., ... Yaseen, G. (2014). An Ethnobotanical Study of Medicinal Plants in High Mountainous Region of Chail Valley (District SwatPakistan). Journal of Ethnobiology and Ethnomedicine, 10(36), 123-128. https://doi.org/10.1186/1746-4269-10-36

Alandia, E. R. (2003). Animal Health Management in a Llama Breeding Project in Ayopaya, Bolivia: Parasitological Survey. Institute of Animal Production in the Tropics and Subtropics, University of Honneheim, Stuttgart, Germany (MSc Thesis).

Alcazar, R. B., Morales, S. M. A., \& Rojas, A. (2003). Livestock Services and the Poor in Bolivia: A Case Study. Danish Agricultural Advisory Centre. Livestock Services and the Poor: A Global Initiative.

Alzérreca, H. (1985). Campos naturales de pastoreo de Bolivia. In Mesa Redonda sobre la Promoción del Manejo de las Praderas Nativas de Sud América. O. Paladines, ed., Santiago, Chile, unpublished mimeo. Retrieved from https://www.researchgate.net/profile/Demis_Andrade/post/Bolivia_needs_for_the_Agricult ural_development/attachment/59d658e879197b80779ae9d2/AS:540316613779457@1505832927861/down load/Bolivia-Pas+For+Eng.pdf.

Alzérreca, H. (1992). Overview of Small Ruminant Research in the Bolivian Andean Zone. In: Valdivia, C. (ed). 
Sustainable Crop-Livestock Systems for the Bolivian Highlands, Proceedings of an SR-CRSP Workshop, Columbia: University of Missouri.

Barreta, J., Gutierrez-Gil, B., Iniguez, V., Romero, F., Saavedra, V., Chiri, R., ... Arranz, J. J. (2013). Analysis of Genetic Diversity in Bolivian Llama Populations using Microsatellites. Journal of Animal Breeding and Genetics, 130(4), 321-330. https://doi.org/10.1111/jbg.12009

Blajos, J., Ojeda, N., Gandarillas, E., \& Gandarillas, A. (2014). Economía de la Quinoa: Perspectivas y Desafios. Revista de Agricultura, 54, 3-10. www.proinpa.org/publico/REVISTA_54_INGLES.pdf

Bonifacio, A., Aroni, G., Villca, M., Ramos, P., Alcon, M., \& Gandarillas, A. (2014). El rol actual y potencial de las q'ila q'ila (Lupinus spp.) en sistemas de produccion sostenible de quinoa. Revista Agricultura, 54, 11-18.

Bryant, F. C., \& Farfan, R. D. (1984). Dry Season Forage Selection by Alpaca [Lama pacos] in Southern Peru. Journal of Range Management, 37(4), 330-333. https://journals.uair.arizona.edu/index.php/jrm/article/download/7735/7347

Chura, B. (2009). Fortalecimiento de la cadena productiva de la quinua real. Descripción de proyecto, Swissaid. Danida. 2004. Farmer Empowerment. Experiences, Lessons Learned and Ways Forward, Vol. 1.

Coppock, D. L., Fernández-Giménez, M., Hiernaux, P., Huber-Sannwald, E., Schloeder, C., Valdivia, C., ... Turner, M. (2017) Rangeland Systems in Developing Nations: Conceptual Advances and Societal Implications. In: Briske D. (Eds) Rangeland Systems. Springer Series on Environmental Management. Springer, Cham. https://doi.org/10.1007/978-3-319-46709-2_17

Estomba, D., Ladio, A., \& Lozada, M. (2006). Medicinal Wild Plant Knowledge and Gathering Patterns in a Mapuche Community from North-western Patagonia. Journal of Ethnopharmacology, 103, 109-119. https://doi.org/10.1016/j.jep.2005.07.015

Fairfield, T. (2004). The Politics of Livestock Sector Policy and the Rural Poor in Bolivia. Rome: Food and Agriculture Organization. Retrieved from http://www.fao.org/ag/againfo/programmes/en/pplpi/docarc/execsumm_wp15.pdf

FAO (2005). Livestock Sector Brief: Bolivia. Retrieved from http://www.fao.org/ag/againfo/resources/en/publications/sector_briefs/lsb_BOL.pdf

Felix, D., \& Villca, C. (2009). Quinua y Territorio. Experiencias de Acompanamiento a la Gestion del Territorio y a la Autogestion Comunal en la Zona Intersalar del Altiplano Boliviano. Agronomes and Veterinaires sans frontieres, 156, 145-153. http://quinua.pe/wp-content/uploads/2016/03/quinoa-y-territorio.pdf

Fonte, S. J., Nesper, M. G., Hegglin, D. J., Velasquez, J. E., Ramirez, B., Rao, I. M., ... Oberson, A. (2014). Pasture Degradation Impacts Soil Phosphorus Storage via Changes to Aggregate-associated Soil Organic Matter in Highly Weathered Tropical Soils. Soil Biology and Biochemistry, 68, 150-157. https://doi.org/10.1016/j.soilbio.2013.09.025

Fugal, R. A., Anderson, V. J., \& Roundy, B. (2010). Exotic Grass and Shrub Production Evaluation and Llama Preference on the Bolivian Altiplano. Small Ruminant Research, 94, 150-160. https://doi.org/10.1016/j.smallrumres.2010.07.019

FUNDES (2009). Desarollo de la Cadena de Camélidos. Main authors: Castro, C., and Estiavariz, M. [Online]. Retrieved from http://infoalpacas.com.pe/wp-content/uploads/2014/02/1654265058.pdf

Genin, D., Villca, Z., \& Abasto, P. (1994). Diet Selection and Utilization by Llama and Sheep in a High Altitude-arid Range Land of Bolivia. Journal of Range Management, 47(3), 245-248. https://journals.uair.arizona.edu/index.php/jrm/article/download/8938/8550

Healy, K. (2001). Llamas, Weavings, and Organic Chocolate: Multicultural Grassroots Development in the Andes and Amazon of Bolivia. Notre Dame, In: University of Notre Dame Press.

INE (2014). Instituto Nacional de Estatistica - Ministerio de Desarollo Rural y Tierras. Retrieved from http://www.ine.gob.bo/indice/general.aspx?codigo $=40116$

Jacobsen, S. E. (2011). The Situation for Quinoa and Its Production in Southern Bolivia: From Economic Success to Environmental Disaster. Journal of Agronomy and Crop Science, 197(5), 390-399. https://doi.org/10.1111/j.1439-037X.2011.00475.x/pdf

Jenet, A., Buono, N., Di Lello, S., Gomarasca, M., Heine, C., Mason, S., .. Van Troos, K. (2016). The Path to 
Greener Pastures. Pastoralism, the Backbone of the World's Drylands. Vétérinaires Sans Frontières International (VSF-International). Brussels, Belgium. Retrieved from http://vsf-international.org/wp-content/uploads/2016/09/REPORT-pastoralism-2017-pag1-1401.pdf

Kim, D.-H., Sexton, J. O., Noojipady, P., Huang, C., Anand, A., Huang, C., ... Townshend, J. R. (2014) Global, Landsat-based forest-cover change from 1990 to 2000. Remote Sensing of Environment, 155, 178-193. https://doi.org/10.1016/j.rse.2014.08.017

Kleier, C., \& Rundel, P. W. (2004). Microsite Requirements, Population Structure and Growth of the Cushion Plant Azorella compacta in the Tropical Chilean Andes. Austral Ecology, 29, 461-470. https://onlinelibrary.wiley.com/doi/epdf/10.1111/j.1442-9993.2004.01386.x

Lambin, E. F., Turner, B. L., Geist, H., Agbola, S., Angelsen, A., Bruce, J. W., ... Xuy, J. (2001). The Causes of Land-use and Land-cover Change: Moving Beyond the Myths. Global Environmental Change, 11(4), 261-269. https://doi.org/10.1016/j.rse.2014.08.017

Martin, G. J. (1995). Ethnobotany: A methods manual. University Press, Cambridge, UK.

Martinez, J. A. (2014). La sostenibilidad para la quinua en riesgo. El Potosi. Viernes, 26 de septiembre de 2014.

Ordonez, T. H. (1994). Llamas, Llama Production and Llama Nutrition in the Ecuador Highlands. Journal of Arid Environments, 26, 67-71. https://doi.org/10.1006/jare.1994.1010

Postigo, J. C., Young, K. R., \& Crews, K. A. (2008). Change and continuity in a pastoralist community in the high Peruvian Andes. Human Ecology, 36, 535-551. https://doi.org/10.1007/s10745-008-9186-1

Reiner, R. J., Bryant, F. C., Farfan, R. D., \& Craddock, B. F. (1987). Forage Intake of Alpacas Grazing Andean Rangeland in Peru. Journal of Animal Science, 64, 868-871. https://doi.org/10.2527/jas1987.643868x

San M. F., \& Bryant, F. C. (1989). Nutrition of Domesticated South American Llamas and Alpacas. Small Ruminant Research, 2, 191-216. https://doi.org/10.1016/0921-4488(89)90001-1

SENAMHI (2014). Servicio Nacional de Meterologia e Hidrologia - Bolivia. Accessed 18 May, 2014 at: http://www.senamhi.gob.bo/meteorologia/formularioboletinmensual.php Signorini, M.A., Piredda, M., \& Bruschi, P. (2009). Plants and Traditional Knowledge: An Ethnobotanical Investigation on Monte Ortobene (Nuoro, Sardinia). Journal of Ethnobiology and Ethnomedicine, 5(6), 1-14. https://doi.org/10.1186/1746-4269-5-6

Stölzl, A. M., Lambertz, C., \& Gauly, M. (2015). Grazing behaviour and dry matter intake of llamas (Lama glama) and German black-head mutton sheep (Ovis orientalis forma aries) under Central European conditions. Berliner und Münchener tierärztliche Wochenschrift, 128(9-10), 409-415.

Treydte, A., Salvatierra, A., Sauerborn, J., \& Lamers, M. (2011). Modelling Llama Population Development under Environmental and Market Constraints in the Bolivian Highlands. Ecological Modelling, 222(17), 3157-3165. https://doi.org/10.1016/j.ecolmodel.2011.05.033

UNHDI. (2016). United Nations Development Programme Human Development Reports. Retrieved from http://hdr.undp.org/en/countries/profiles/BOL (accessed May 14, 2018)

Van Saun, R. J. (2006). Nutritional diseases of South American camelids. Small Ruminant Research, 61, 153-164.

Vera, R. R. (2006). Country Pasture/Forage Resource Profile: Bolivia. Food and Agriculture Organization (FAO). Retrieved from www.fao.org/ag/AGP/AGPC/doc/counprof/PDF\%20files/Bolivia-English.pdf

Vidaurre, P. J., Paniagua, N., \& Moraes, R. M. (2006). Ethnobotánica en los Andes de Bolivia. Botánica Económica de los Andes Centrales. Universidad Mayor de San Andrés, La Paz, pp. 224-238.

Villagrán, C., \& Castro, V. (2004). Ciencia Indíghena de los Andes del Norte de Chile. Primera Edición. Imprenta Salesianos S.A., Santiage de Chile.

ZONISIG (2000). Zonificacion Agroecologica y Socioeconomica, Departamento de Potosi, Bolivia. ZONISIG, Proyecto Zonificación Agroecológica y Establecimiento de una Base de Datos y Red de Sistema de Información Geográfica en Bolivia. 
Appendix 1: Base inventory plant list

\begin{tabular}{|c|c|c|c|c|c|}
\hline $\begin{array}{l}\text { Plant } \\
\text { Classifications }\end{array}$ & Botanical Species & \multirow{2}{*}{$\begin{array}{l}\text { Vernacular } \\
\text { Name } \\
\text { Espinas }\end{array}$} & \multirow[t]{2}{*}{$\begin{array}{l}\text { Botanical } \\
\text { Family }\end{array}$} & \multirow{2}{*}{$\begin{array}{l}\begin{array}{l}\text { Local Distribution } \\
\text { (see below) }\end{array} \\
1,2,3,4\end{array}$} & \multirow[t]{2}{*}{ Other Uses } \\
\hline Plant Habitat/ & & & & & \\
\hline \multicolumn{6}{|l|}{ Ethnogroup } \\
\hline & & Leñas/Tolas & & $1,2,3,4$ & \\
\hline & & Pastos verdes & & $1,4 \& 5$ & \\
\hline & & Bofedal & & 3 & \\
\hline & & Ichu/Paja & & $1,2,3$ & \\
\hline \multirow[t]{2}{*}{ Crop Residues } & Vicia faba $\mathrm{L}$. & Hipis de haba & Fabaceae & 7 & \\
\hline & $\begin{array}{l}\text { Chenopodium } \\
\text { quinoa Willd. }\end{array}$ & $\begin{array}{l}\text { Hipis de } \\
\text { Quinoa }\end{array}$ & $\begin{array}{l}\text { Amaranthace } \\
\text { ae }\end{array}$ & 7 & \\
\hline \multirow[t]{4}{*}{ Cultivate Crops } & Mentha spp. & Hierbabuena & Lamiaceae & 7 & $\begin{array}{l}\text { Medicinal: used to treat stomach pain, diarrhoea, colds and coughs. Preparation: } \\
\text { herbal infusion with leaves. }\end{array}$ \\
\hline & Hordeum vulgare $\mathrm{L}$. & Cebada & Poaceae & 7 & \\
\hline & Medicago sativa $\mathrm{L}$. & Alfalfa & Fabaceae & 7 & \\
\hline & $\begin{array}{l}\text { Linum usitatissimum } \\
\text { L. }\end{array}$ & Linaza & Linaceae & 7 & $\begin{array}{l}\text { Medicinal: used for stomach pain and fevers. Preparation: toast and boil seeds. } \\
\text { Drink as a tea. }\end{array}$ \\
\hline \multicolumn{6}{|l|}{ Native Forage Species } \\
\hline \multicolumn{6}{|l|}{ Grasses (Paja / Ichu) } \\
\hline Festuca orthophylla $\mathrm{F}$ & & Paja brava & Poaceae & $1,2,3$ & \\
\hline Stipa cf. chrysopylla & Desv. & Sikuya & Poaceae & 1,3 & \\
\hline Bromus cf. catharticu & Vahl. & Cedabilla & Poaceae & 1,3 & $\begin{array}{l}\text { Medicinal: used to treat rheumatism and body aches. } \\
\text { Said to provide energy when consume a herbal infusion of the vegetative parts. }\end{array}$ \\
\hline Festuca dolichophyll & J. Presl. & Chillihua & Poaceae & $1,2,3$ & \\
\hline Deyeuxia cf. curvula & Vedd. & Chiqu chiqu & Poaceae & 1,3 & \\
\hline Deyeuxia sp. & & Caorayo & Poaceae & 6 & \\
\hline Chondrosum cf. simp & $x$ (Lag.) Kunth & Llapa & Poaceae & $1,3,5$ & \\
\hline Chondrosum sp. & & Llapa roja & Poaceae & $1,2,3,5$ & \\
\hline \multicolumn{6}{|l|}{ Spinose (Espinas) } \\
\hline \multicolumn{2}{|c|}{ Adesmia cf. miraflorensi Remy } & Churky & Fabaceae & 2,4 & $\begin{array}{l}\text { Medicinal: used to treat colds and coughs. } \\
\text { Preparation: herbal infusion with leaves and flowers. } \\
\text { Also used as firewood. }\end{array}$ \\
\hline \multicolumn{2}{|l|}{ Adesmia spp. } & *Añawaya & Fabaceae & 2,4 & $\begin{array}{l}\text { Medicinal: used to treat colds and coughs. } \\
\text { Preparation: herbal infusion with leaves and flowers. } \\
\text { Also used as firewood. }\end{array}$ \\
\hline \multicolumn{2}{|c|}{ Tetraglochin cristatum (Britton) Rothm. } & Llucho & Rosaceae & 2,4 & $\begin{array}{l}\text { Medicinal: used to treat colds and coughs. } \\
\text { Preparation: herbal infusion with leaves and flowers. } \\
\text { Also used as firewood. }\end{array}$ \\
\hline \multicolumn{2}{|c|}{$\begin{array}{l}\text { Junellia seriphioides (Gillies \& Hook.) } \\
\text { Moldenke }\end{array}$} & $\begin{array}{l}\text { Haraquiska } \\
\text { (Largarta } \\
\text { espinosa) }\end{array}$ & Verbenaceae & $1,2,4$ & $\begin{array}{l}\text { Medicinal: used to treat stomach pain, coughs, colds, and body aches. } \\
\text { Preparation: flowers prepared into a herbal tea. } \\
\text { Also used as firewood. }\end{array}$ \\
\hline \multicolumn{2}{|c|}{ Ephedra cf. breana Phil. } & $\begin{array}{l}\text { Cola de } \\
\text { Caballo } \\
\text { Pinkopinko }\end{array}$ & Ephedraceae & 4 & $\begin{array}{l}\text { Medicinal: roots, stem, leaves, flowers, \& fruits consumed to treat stomach pain, } \\
\text { colds, and bone pain. } \\
\text { Also used to treat bladder and urinary infections. Purgative. Preparation: herbal } \\
\text { infusion of leaves and stem. }\end{array}$ \\
\hline \multicolumn{2}{|c|}{ Chuquiraga atacamensis Kuntze } & $\begin{array}{l}\text { Hakataka } \\
\text { Chio'kiska }\end{array}$ & Asteraceae & 2,4 & $\begin{array}{l}\text { Good forage plant, animals consume young shoots. } \\
\text { Medicinal: used for stomach pain, body pain, colds, and dry cough. Cleanse the } \\
\text { body after birth and has abortive effects. } \\
\text { Also used as firewood sometimes, but not often. }\end{array}$ \\
\hline \multirow{2}{*}{\multicolumn{2}{|c|}{ Opuntia cf. soehrensii Britton \& Rose }} & $\begin{array}{l}\text { Leko } \\
\text { Airampu } \\
\text { Ayrampu }\end{array}$ & Cactaceae & $1,2,4$ & $\begin{array}{l}\text { Edible fruits. Fruits used to dye fabric. } \\
\text { Medicinal: used to treat liver and kidney infections. } \\
\text { Vermicide. Preparation: fruit boiled into herbal infusion or made into fresh juice. } \\
\text { Toxic: some claim that it is toxic when animals consume vegetative parts. }\end{array}$ \\
\hline & & $\begin{array}{l}\text { Tayakchi } \\
\text { Tacaysiña }\end{array}$ & Cactaceae & 4 & $\begin{array}{l}\text { Medicinal: fruit consumed to treat stomach, gallbladder, liver, and kidney } \\
\text { infections. Laxative. }\end{array}$ \\
\hline \multicolumn{2}{|l|}{ \& Rose } & & & & Edible fruits. Fruit consumed fresh. \\
\hline \multicolumn{6}{|l|}{ Shrubs (Tolas) } \\
\hline \multicolumn{2}{|c|}{ Baccharis tola Phil. subsp. Tola } & Ñaka & Asteraceae & $1,2,4$ & $\begin{array}{l}\text { Medicinal: used to treat cold, coughs, and stomach pain. Preparation: toast leaves } \\
\text { and serve as an herbal infusion. } \\
\text { Forage plant when young (tender). Good forage plant overwinter, when forages are } \\
\text { limited. } \\
\text { Also used as firewood. } \\
\text { Ceremonial uses as incense. }\end{array}$ \\
\hline \multirow{3}{*}{$\begin{array}{l}\text { Parastrephia } \\
\text { Cabrera }\end{array}$} & angularis (Meyen) & T'iti & Asteraceae & $1,2,4$ & Medicinal: antibiotic properties \\
\hline & & & & & Preparation: herbal infusion from leaves \\
\hline & & & & & Also used as firewood \\
\hline
\end{tabular}




\begin{tabular}{|c|c|c|c|c|}
\hline Fabiana cf. denudata Miers & Tara tara & Solanaceae & $1,2,4$ & $\begin{array}{l}\text { Ceremonial use as incense; in funerals and purification ceremonies. } \\
\text { Medicinal: used to treat broken bones and cuts. Preparation: grind green parts of } \\
\text { plant into pomace mixed with wheat flour and placed over wound. Can also be } \\
\text { mixed with bird (Agriornis) guano and egg yolks, or urine to make a plaster. Also } \\
\text { used for coughs and colds. } \\
\text { Also used as firewood. }\end{array}$ \\
\hline Parastrephia lepidophylla (Wedd.) Cabrera & $\begin{array}{l}\text { Quiruta } \\
\text { Suputola }\end{array}$ & Asteraceae & $1,2,4$ & $\begin{array}{l}\text { Medicinal: used to treat fevers, cough, and stomach and bile infections. } \\
\text { Preparation: herbal infusion with leaves. } \\
\text { Ceremonial uses as incense. } \\
\text { Also used as firewood. }\end{array}$ \\
\hline Lampaya medicinalis Phil. & Lampaya & Verbenaceae & 1,3 & $\begin{array}{l}\text { Medicinal: used to treat cough and colds. Reported use of treating skin infections } \\
\text { (scabies). } \\
\text { Preparation: herbal infusion from stems leaves and flowers. Toast the leaves and } \\
\text { stem and make a tea mixed with lemon. Apply as a pomace to skin infections. } \\
\text { Also used as firewood. }\end{array}$ \\
\hline & K'nya & Asteraceae & $1,2,3$ & \\
\hline Baccharis cf. acaulis (Wedd. ex R.E. Fries) & & & & \\
\hline Parastrephia lucida (Meyen) Cabrera & Umatola & Asteraceae & $1,2,4$ & $\begin{array}{l}\text { Medicinal: used to treat fractures and broken bones. Preparation: grind leaves and } \\
\text { apply as pomace. } \\
\text { Also used as an herbal infusion of leaves to treat lung infections, fevers, and tooth } \\
\text { pain. } \\
\text { Also used as firewood. }\end{array}$ \\
\hline $\begin{array}{l}\text { Chersodoma jodopappa (Sch.Bip. ex Wedd.) } \\
\text { Cabrera }\end{array}$ & Oqetola & Asteraceae & 1,4 & $\begin{array}{l}\text { Medicinal: used to treat headaches, colds, coughs, and stomach pain. } \\
\text { Preparation: boil leaves in an herbal infusion. }\end{array}$ \\
\hline Herbaceous Plants (Pastos Verdes) & & & & \\
\hline Tarasa tenella (Cav.) Krapov. & *Malva & Malvaceae & $1,2,3,5$ & \\
\hline Schkuhria sp. & $\begin{array}{l}\text { Hamacura } \\
\text { Pasto del } \\
\text { campo }\end{array}$ & Asteraceae & 1,5 & \\
\hline Tagetes multiflora Kunth & Suico & Asteraceae & $1,2,3,5$ & $\begin{array}{l}\text { Medicinal: used to treat stomach pains, bloating, gastrointestinal problems and } \\
\text { produces soothing effects. } \\
\text { Preparation: herbal infusion with flowers and leaves. }\end{array}$ \\
\hline Northoscordum andicola Kunth & $\begin{array}{l}\text { Muchuguna } \\
\text { Cebollin }\end{array}$ & $\begin{array}{l}\text { Amaryllidace } \\
\text { ae }\end{array}$ & $1,2,3,5$ & Edible tuber \\
\hline Hoffmannseggia doellii Phil. subsp. doellii & $\begin{array}{l}\text { Mutucura } \\
\text { Mutucuru }\end{array}$ & Fabaceae & $1,2,3,5$ & Edible tuber \\
\hline Senecio mathewssi Wedd. & Pasto lloron & Asteraceae & $1,3,6$ & \\
\hline Nototriche longirostris (Wedd.) A.W. Hill & Tuluma pasto & Malvaceae & $1,3,5$ & \\
\hline Chenopodium ambrosioides $\mathrm{L}$. & $\begin{array}{l}\text { Quinoa de } \\
\text { paloma } \\
\text { Payko }\end{array}$ & $\begin{array}{l}\text { Amaranthace } \\
\text { ae }\end{array}$ & 5 & $\begin{array}{l}\text { Medicinal: used to treat stomach pain and diaahrea. Preparation: herbal infusion } \\
\text { with vegetative parts. }\end{array}$ \\
\hline Oxychloe cf. andina Phil. & $\begin{array}{l}* \text { Paco } \\
\text { Pacoya }\end{array}$ & Juncaceae & 3,6 & Paco $=$ any edible grass in Quechua \\
\hline Xenophyllum cf. popusum (Phil.) V.A. Funk & Pupusa & Asteraceae & 6 & $\begin{array}{l}\text { Medicinal: antibiotic properties. Preparation: herbal infusion with leaves } \\
\text { Ceremonial uses as incense. }\end{array}$ \\
\hline Atriplex cf. imbricata (Moq.) D. Dietr. & $\begin{array}{l}\text { Piñaya } \\
\text { Piyaya }\end{array}$ & $\begin{array}{l}\text { Amaranthace } \\
\text { ae }\end{array}$ & $1,3,4,5$ & $\begin{array}{l}\text { Good forage plant, animals gain weight from eating this plant. Maintains during } \\
\text { dry season. } \\
\text { Edible leaves. }\end{array}$ \\
\hline Wetland (Bofedal) & & & & \\
\hline Azorella compacta Phil. & Yareda & Apiaceae & 6 & $\begin{array}{l}\text { Medicinal: Roots, flower, seeds, \& resin consumed to treat liver \& gall bladder } \\
\text { infections, cough, diabetes, pain (tooth), and purify the blood. Infusion of the root } \\
\text { used to treat 'women's pain' and gastrointestinal problems. } \\
\text { Preparation: herbal infusion from all parts. }\end{array}$ \\
\hline Sarcocornia pulvinata (R.E. Fries) A.J. Scott & $\begin{array}{l}\text { Yankiyanki } \\
\text { Anke } \\
\text { Janke }\end{array}$ & $\begin{array}{l}\text { Amaranthace } \\
\text { ae }\end{array}$ & 3,6 & $\begin{array}{l}\text { Janke/Janki/Anke/Anki = alludes to the action of ingesting forage in Quechua } \\
\text { (Chile flora, pg. 171) }\end{array}$ \\
\hline Gomphrena pumila Gillies ex Moq. & Alchi alchi & $\begin{array}{l}\text { Amaranthace } \\
\text { ae }\end{array}$ & $3,5,6$ & \\
\hline Lobelia oligophylla (Wedd.) Lammers & $\begin{array}{l}\text { Begal } \\
* \text { Vega } \\
* \text { Cienigo }\end{array}$ & $\begin{array}{l}\text { Campanulace } \\
\text { ae }\end{array}$ & 6 & \\
\hline $\begin{array}{l}\text { Azorella cf. biloba (Schltdl.) Wedd } \\
\text { Non-Categorized }\end{array}$ & Cangiui & Apiaceae & 6 & \\
\hline Graephalium spp. & $\begin{array}{l}\text { Vira Vira } \\
\text { Wira Wira }\end{array}$ & Asteraceae & 4 & $\begin{array}{l}\text { Medicinal: used to treat headaches, colds and coughs. } \\
\text { Preparation: use leaves as a herbal infusion }\end{array}$ \\
\hline Solanum sarrachoides Sendtn. & $\begin{array}{l}\text { azul tika } \\
\text { papa silvestre }\end{array}$ & Solanaceae & $1,2,3,5$ & \\
\hline
\end{tabular}




\begin{tabular}{|c|c|c|c|c|}
\hline Astragalus garbancillo Cav. & Garboncillo & Fabaceae & $1,2,3,5$ & Toxic: causes bloating and constipation in animals. \\
\hline \multirow[t]{3}{*}{ Loasa grandiflora Desr. } & Itapayo & Loasaceae & 4 & Toxic: harmful when consumed as forage. \\
\hline & Ortiga macho & & & \\
\hline & Itapallo & & & \\
\hline Cheilianthes pruinata Kaulf. & Chujchu & Pteridaceae & $1,2,4$ & Toxic: provokes fever and rigors in animals when consumed \\
\hline \multirow[t]{2}{*}{ Clinopodium bolivianum (Benth.) Kunth } & Muña & Lamiaceae & 4 & $\begin{array}{l}\text { Medicinal: used to treat stomach and intestinal pains as well as antibiotic } \\
\text { properties }\end{array}$ \\
\hline & & & & Preparation: herbal infusion with leaves and flowers \\
\hline \multirow[t]{4}{*}{ Senecio cf. nutans Sch.Bip. } & Chakacoma & Asteraceae & 4 & $\begin{array}{l}\text { Medicinal: used to treat altitude sickness, stomach pain, body aches, fever, } \\
\text { coughs, colds, and flatulence. }\end{array}$ \\
\hline & & & & Preparation: herbal infusion with leaves. Inhale smoke of leaves to cure rhinorrhea. \\
\hline & & & & Pomace made from grinding leaves and applied to soothe pain. \\
\hline & & & & Edible leaves used in cooking as spice. \\
\hline Lupinus oreophilus Phil. & Kela & Fabaceae & $1,2,3,5$ & $\begin{array}{l}\text { Toxic: can be toxic when consumed as fresh forage. Needs to be cut and dried if } \\
\text { using as forage for animals. }\end{array}$ \\
\hline
\end{tabular}

\begin{tabular}{l}
$*$ sub-ethno group \\
\hline 1 = pampa (plains/grasslands) \\
2 = pampa alta (high plains/grasslands) \\
$3=$ pampa baja (low plains/grassland) \\
$4=$ quebrada (ravine, mountain) \\
$5=$ chacras en descansa (fallow fields) \\
$6=$ bofedal (wetlands) \\
$7=$ chacras (home garden/plots) \\
\hline
\end{tabular}


Appendix II: Relative frequency citation (RFC) results

\begin{tabular}{|c|c|c|c|c|c|c|c|c|c|c|c|c|c|c|c|c|c|c|c|}
\hline \multirow{4}{*}{ Botanical Species } & \multirow{4}{*}{$\begin{array}{l}\text { Vernaculare } \\
\text { Name }\end{array}$} & \multicolumn{6}{|c|}{ Site 1} & \multicolumn{6}{|c|}{ Site 2} & \multicolumn{6}{|c|}{ Site 3} \\
\hline & & \multirow{3}{*}{$\mathbf{N}$} & \multirow{3}{*}{$\mathbf{F}$} & \multicolumn{2}{|c|}{ Indices } & \multicolumn{2}{|c|}{ Ranking } & \multirow{3}{*}{$\mathbf{N}$} & \multirow{3}{*}{$\mathbf{F}$} & \multicolumn{2}{|c|}{ Indices } & Ran & king & & & & dices & Ran & king \\
\hline & & & & & Average & & & & & & Average & & & $\mathbf{N}$ & $\mathbf{F}$ & & Averag & & RFC \\
\hline & & & & RFC & RFCi & RFC & RFCi & & & RFC & RFCi & RFC & RFCi & & & RFC & e RFCi & RFC & i \\
\hline & Espinas & 12 & 40 & 1.00 & 0.1147 & 1 & 1 & 11 & 47 & 0.73 & 0.0891 & 3 & 4 & 10 & 17 & 0.71 & 0.0701 & 3 & 4 \\
\hline & Leñas/Tolas & 12 & 31 & 1.00 & 0.0840 & 1 & 3 & 14 & 38 & 0.93 & 0.1226 & 2 & 1 & 13 & 38 & 0.93 & 0.1433 & 2 & 2 \\
\hline & Pastos verdes & 10 & 15 & 0.83 & 0.0426 & 3 & 7 & 4 & 4 & 0.27 & 0.0173 & 9 & 15 & 4 & 4 & 0.29 & 0.0180 & 8 & 19 \\
\hline & Bofedal & 2 & 3 & 0.17 & 0.0058 & 10 & 29 & 15 & 30 & 1.00 & 0.1134 & 1 & 2 & 13 & 22 & 0.93 & 0.0887 & 2 & 3 \\
\hline & Ichu/Paja & 10 & 25 & 0.83 & 0.0721 & 3 & 4 & 14 & 29 & 0.93 & 0.0980 & 2 & 3 & 14 & 36 & 1.00 & 0.1576 & 1 & 1 \\
\hline Vicia faba $\mathrm{L}$. & Hipis de haba & 6 & 7 & 0.50 & 0.0220 & 6 & 13 & 5 & 6 & 0.33 & 0.0253 & 8 & 11 & 4 & 6 & 0.29 & 0.0238 & 8 & 15 \\
\hline Chenopodium quinoa Willd. & Hipis de Quinoa & 6 & 8 & 0.50 & 0.0228 & 6 & 11 & 3 & 5 & 0.20 & 0.0163 & 10 & 17 & 1 & 1 & 0.07 & 0.0036 & 11 & 29 \\
\hline Mentha spp. & Hierbabuena & 0 & 0 & 0 & 0 & - & - & 4 & 4 & 0.27 & 0.0157 & 9 & 18 & 2 & 2 & 0.14 & 0.0074 & 10 & 24 \\
\hline Hordeum vulgare $\mathrm{L}$. & Cebada & 4 & 5 & 0.33 & 0.0178 & 8 & 17 & 8 & 15 & 0.53 & 0.0635 & 5 & 6 & 6 & 8 & 0.43 & 0.0363 & 6 & 7 \\
\hline Medicago sativa $\mathrm{L}$. & Alfalfa & 5 & 6 & 0.42 & 0.0137 & 7 & 20 & 10 & 23 & 0.67 & 0.0724 & 4 & 5 & 6 & 9 & 0.43 & 0.0448 & 6 & 6 \\
\hline Linum usitatissimum $\mathrm{L}$. & Linaza & 0 & 0 & 0 & 0 & - & - & 1 & 1 & 0.07 & 0.0027 & 12 & 32 & 0 & 0 & 0 & 0 & - & - \\
\hline Grasses (Paja / Ichu) & & & & & & & & & & & & & & & & & & & \\
\hline Festuca orthophylla Pilg. & Paja brava & 5 & 6 & 0.42 & 0.0170 & 7 & 18 & 10 & 13 & 0.67 & 0.0392 & 4 & 9 & 6 & 8 & 0.43 & 0.0278 & 6 & 11 \\
\hline Stipa cf. chrysopylla E. Desv. & Sikuya & 3 & 4 & 0.25 & 0.0116 & 9 & 22 & 0 & 0 & 0 & 0 & - & - & 0 & 0 & 0 & 0 & - & - \\
\hline Bromus cf. catharticus Vahl. & Cedabilla & 6 & 11 & 0.50 & 0.0341 & 6 & 8 & 3 & 5 & 0.20 & 0.0121 & 10 & 22 & 1 & 1 & 0.07 & 0.0032 & 11 & 30 \\
\hline Festuca dolichophylla J. Presl. & Chillihua & 0 & 0 & 0 & 0 & - & - & 0 & 0 & 0 & 0 & - & - & 1 & 2 & 0.07 & 0.0068 & 11 & 25 \\
\hline Deyeuxia cf. curvula Wedd. & Chiqu Chiqu & 5 & 9 & 0.42 & 0.0241 & 7 & 10 & 2 & 3 & 0.13 & 0.0066 & 11 & 26 & 2 & 4 & 0.14 & 0.0151 & 10 & 20 \\
\hline Deyeuxia sp. & Caorayo & 0 & 0 & 0 & 0 & - & - & 0 & 0 & 0 & 0 & - & - & 1 & 2 & 0.07 & 0.0062 & 11 & 26 \\
\hline Chondrosum cf. simplex (Lag.) & & & & & & & & & & & & & & & & & & & \\
\hline Kunth & Llapa & 8 & 24 & 0.67 & 0.0690 & 4 & 5 & 2 & 2 & 0.13 & 0.0082 & 11 & 24 & 0 & 0 & 0 & 0 & - & - \\
\hline Chondrosum sp. & Llapa roja & 1 & 1 & 0.08 & 0.0017 & 11 & 35 & 0 & 0 & 0 & 0 & - & - & 0 & 0 & 0 & 0 & - & - \\
\hline Spinose (Espinas) & & & & & & & & & & & & & & & & & & & \\
\hline Adesmia cf. miraflorensi Remy & Churky & 5 & 7 & 0.42 & 0.0153 & 7 & 19 & 0 & 0 & 0 & 0 & - & - & 0 & 0 & 0 & 0 & - & - \\
\hline Adesmia spp. & *Añawaya & 8 & 11 & 0.67 & 0.0319 & 4 & 9 & 7 & 16 & 0.47 & 0.0477 & 6 & 8 & 0 & 0 & 0 & 0 & - & - \\
\hline Tetraglochin cristatum (Britton) & & & & & & & & & & & & & & & & & & & \\
\hline Rothm. & Llucho & 7 & 8 & 0.58 & 0.0206 & 5 & 15 & 0 & 0 & 0 & 0 & - & - & 0 & 0 & 0 & 0 & - & - \\
\hline & Haraquiska & & & & & & & & & & & & & & & & & & \\
\hline Junellia seriphioides (Gillies \& & (Largarta & & & & & & & & & & & & & & & & & & \\
\hline Hook.) Moldenke & espinosa) & 4 & 4 & 0.33 & 0.0087 & 8 & 28 & 0 & 0 & 0 & 0 & - & - & 0 & 0 & 0 & 0 & - & - \\
\hline & Cola de Caballo & & & & & & & & & & & & & & & & & & \\
\hline & Pingo pingo & & & & & & & & & & & & & & & & & & \\
\hline Ephedra cf. breana Phil. & Pinko pinko & 1 & 1 & 0.08 & 0.0017 & 11 & 35 & 0 & 0 & 0 & 0 & - & - & 0 & 0 & 0 & 0 & - & - \\
\hline & Hakataka & & & & & & & & & & & & & & & & & & \\
\hline Chuquiraga atacamensis Kuntze & Chio'kiska & 3 & 4 & 0.25 & 0.0104 & 9 & 23 & 0 & 0 & 0 & 0 & - & - & 0 & 0 & 0 & 0 & - & - \\
\hline & Leko & & & & & & & & & & & & & & & & & & \\
\hline Opuntia cf. soehrensii Britton \& & Airampu & & & & & & & & & & & & & & & & & & \\
\hline Rose & Ayrampu & 5 & 5 & 0.42 & 0.0128 & 7 & 21 & 1 & 1 & 0.07 & 0.0020 & 12 & 34 & 0 & 0 & 0 & 0 & - & - \\
\hline Corryocactus brevistylus (K. & Tayakchi & & & & & & & & & & & & & & & & & & \\
\hline Schum.) Britton \& Rose & Tacaysiña & 0 & 0 & 0 & 0 & - & - & 0 & 0 & 0 & 0 & - & - & 1 & 1 & 0.07 & 0.0032 & 11 & 30 \\
\hline Shrubs (Tolas) & & & & & & & & & & & & & & & & & & & \\
\hline Baccharis tola Phil. subsp. tola & Ñaka & 4 & 4 & 0.33 & 0.0089 & 8 & 25 & 5 & 8 & 0.33 & 0.0209 & 8 & 12 & 5 & 6 & 0.36 & 0.0211 & 7 & 17 \\
\hline Parastrephia quadrangularis & & & & & & & & & & & & & & & & & & & \\
\hline (Meyen) Cabrera & T'iti & 4 & 4 & 0.33 & 0.0089 & 8 & 25 & 1 & 2 & 0.07 & 0.0053 & 12 & 27 & 7 & 7 & 0.50 & 0.0252 & 5 & 13 \\
\hline Fabiana cf. denudata Miers & Tara tara & 7 & 8 & 0.58 & 0.0207 & 5 & 14 & 5 & 7 & 0.33 & 0.0202 & 8 & 13 & 3 & 3 & 0.21 & 0.0103 & 9 & 22 \\
\hline Parastrephia & Quiruta & & & & & & & & & & & & & & & & & & \\
\hline (Wedd.) Cabrera & Suputola & 7 & 7 & 0.58 & 0.0183 & 5 & 16 & 8 & 17 & 0.53 & 0.0488 & 5 & 7 & 7 & 8 & 0.50 & 0.0273 & 5 & 12 \\
\hline Lampaya medicinalis Phil. & Lampaya & 2 & 2 & 0.17 & 0.0053 & 10 & 30 & 0 & 0 & 0 & 0 & - & - & 6 & 8 & 0.43 & 0.0286 & 6 & 9 \\
\hline Baccharis cf. acaulis (Wedd. ex & & & & & & & & & & & & & & & & & & & \\
\hline R.E. Fries) & K'nya & 0 & 0 & 0 & 0 & - & - & 3 & 3 & 0.20 & 0.0092 & 10 & 23 & 2 & 2 & 0.14 & 0.0104 & 10 & 21 \\
\hline Parastrephia lucida (Meyen) & & & & & & & & & & & & & & & & & & & \\
\hline Cabrera & Umatola & 0 & 0 & 0 & 0 & - & - & 1 & 1 & 0.07 & 0.0030 & 12 & 31 & 0 & 0 & 0 & 0 & - & - \\
\hline
\end{tabular}




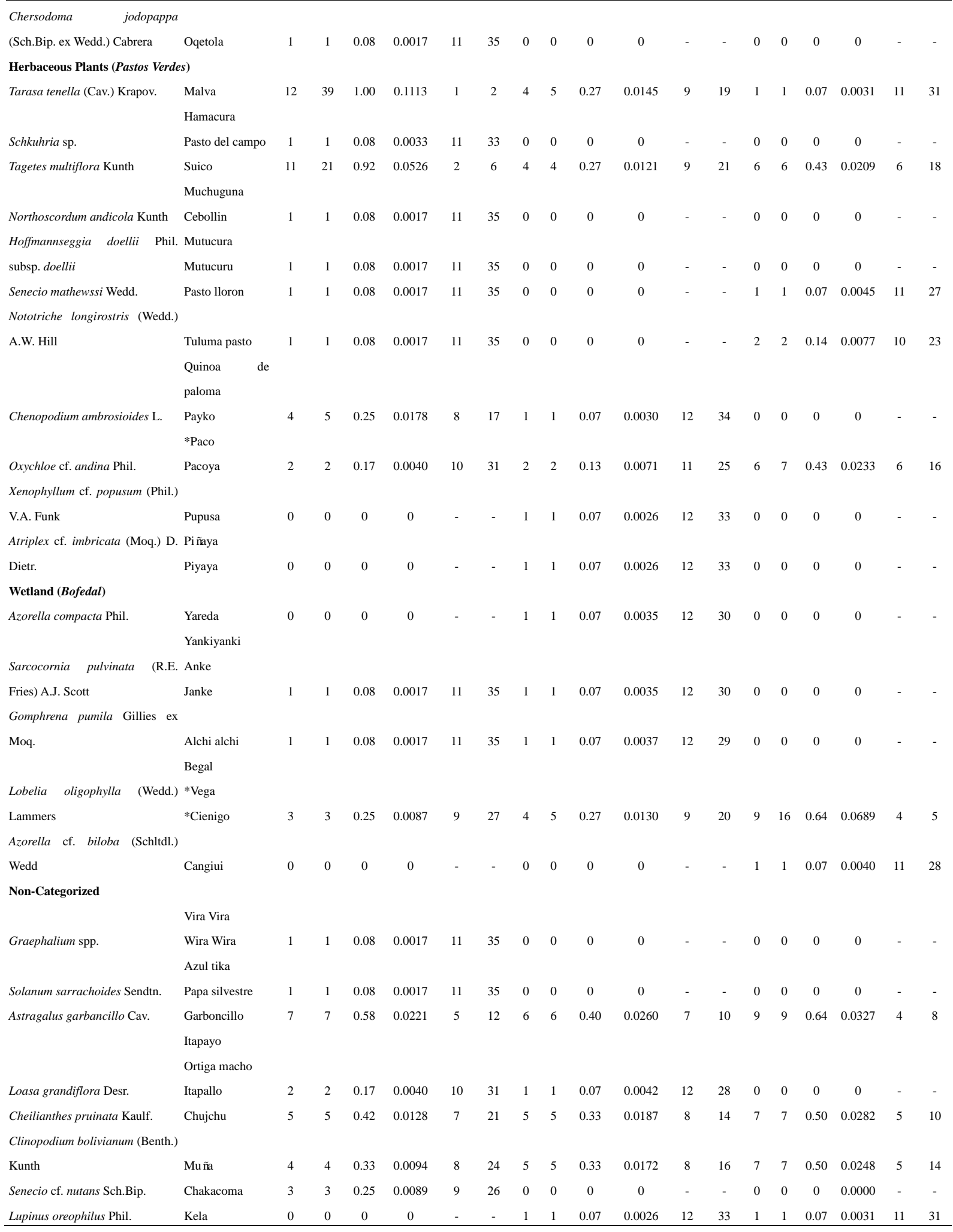

\section{Copyrights}

Copyright for this article is retained by the author(s), with first publication rights granted to the journal.

This is an open-access article distributed under the terms and conditions of the Creative Commons Attribution license (http://creativecommons.org/licenses/by/3.0/). 